NBER WORKING PAPER SERIES

\title{
A MULTINATIONAL PERSPECTIVE ON \\ CAPITAL STRUCTURE CHOICE AND INTERNAL CAPITAL MARKETS
}

\author{
Mihir A. Desai \\ C. Fritz Foley \\ James R. Hines Jr. \\ Working Paper 9715 \\ http://www.nber.org/papers/w9715
NATIONAL BUREAU OF ECONOMIC RESEARCH
1050 Massachusetts Avenue
Cambridge, MA 02138 \\ May 2003
}

The statistical analysis of firm-level data on U.S. multinational companies was conducted at the International Investment Division, Bureau of Economic Analysis, U.S. Department of Commerce under arrangements that maintain legal confidentiality requirements. The views expressed are those of the authors and do not reflect official positions of the U.S. Department of Commerce. We thank William Zeile for helpful comments, and the Lois and Bruce Zenkel Research Fund at the University of Michigan and the Division of Research at Harvard Business School for financial support. The views expressed herein are those of the authors and not necessarily those of the National Bureau of Economic Research.

(C2003 by Mihir A. Desai, C. Fritz Foley, and James R. Hines Jr.. All rights reserved. Short sections of text not to exceed two paragraphs, may be quoted without explicit permission provided that full credit including (C) notice, is given to the source. 
A Multinational Perspective on Capital Structure Choice and Internal Capital Markets

Mihir A. Desai, C. Fritz Foley, and James R. Hines Jr.

NBER Working Paper No. 9715

May 2003

JEL No. G32, H25, G38, F23

\begin{abstract}
This paper examines the impact of local tax rates and capital market conditions on the level and composition of borrowing by foreign affiliates of American multinational corporations. The evidence indicates that 10 percent higher local tax rates are associated with 2.8 percent higher debt/asset ratios of American-owned affiliates, and that borrowing from related parties is particularly sensitive to tax rates. Borrowing by American affiliates responds to local inflation and political risks, and is more costly in countries with underdeveloped capital markets and those providing weak legal protections for creditors. Affiliates in environments where external borrowing is costly borrow less from unrelated parties: one percent higher interest rates are associated with 1.4 to 2.0 percent less external debt as a fraction of assets. Instrumental variables analysis reveals that affiliates substitute loans from parent companies for between half and three quarters of the reduced borrowing from unrelated parties stemming from adverse local capital market conditions. These patterns suggest that multinational firms are able to structure their finances in response to tax and capital market conditions, thereby creating opportunities not available to many of their local competitors.
\end{abstract}

\author{
Mihir A. Desai \\ Harvard Business School \\ Morgan 363 \\ Soldiers Field \\ Boston, MA 02163 \\ and NBER \\ mdesai@hbs.edu
}

\author{
C. Fritz Foley \\ University of Michigan \\ Business School \\ 701 Tappan Street \\ Ann Arbor, MI 48109-1234 \\ ffoley@umich.edu
}

\author{
James R. Hines Jr. \\ University of Michigan \\ Business School \\ 701 Tappan Street \\ Ann Arbor, MI 48109-1234 \\ and NBER \\ jrhines@umich.edu
}




\section{Introduction}

To what extent does corporate borrowing increase due to the tax deductibility of interest expenses and decline in response to costs imposed by capital market underdevelopment or unfavorable legal systems? Do firms use internal capital markets to substitute for external finance when the latter is costly, and if so, how extensive is such substitution? Empirical attempts to answer these fundamental questions face significant challenges. Limited variation in tax incentives within countries makes it difficult to identify the effects of taxes, and detailed information on the workings of internal capital markets is scarce. Recent efforts using cross-country samples exploit the rich variation that international comparisons offer, but frequently face problems associated with nonstandardized measurement across countries and limited statistical power due to small sample sizes.

Cross-country studies of capital structure commonly ignore the many wrinkles associated with multinational firms. These firms face differing tax incentives and legal regimes around the world, making it possible to identify the impact of these factors on financing choices. Analysis of the behavior of multinational firms promises clean estimates of the sensitivity of capital structure choice to tax incentives, an understanding of the mechanisms by which weak capital markets alter financing choices, and insight into the ways in which internal capital markets can facilitate tax minimization and provide an alternate financing source when external financing is most costly.

This paper analyzes determinants of the capital structures of foreign affiliates of U.S. multinational firms. The use of confidential affiliate-level data makes it possible to distinguish the behavior of foreign affiliates of the same parent companies operating in markets with differing tax rates and capital market regimes, and to differentiate the determinants of internal and external borrowing. As a result, it is possible to obtain clean estimates of the impact of taxation and local capital market conditions while implicitly controlling for considerations that are common to all affiliates of the same company. The sample includes information on the activities of roughly 3,700 U.S. multinational firms operating in more than 150 countries through approximately 30,000 affiliates in 1982, 1989, 
and 1994. Since all reporting follows generally accepted U.S. accounting principles, and all financial information is filed through U.S. entities familiar with such practices, it is not necessary to make problematic assumptions normally required in order to analyze financial information collected in different countries.

Three empirical findings emerge from the regressions. First, there is strong evidence that affiliates of multinational firms alter the level and composition of debt in response to tax incentives and capital market conditions. The estimates imply that 10 percent higher tax rates are associated with 2.8 percent greater debt as a fraction of assets, and firms borrow less in countries with underdeveloped capital markets and poor legal protections for creditors. Internal finance is particularly sensitive to tax differences. While the estimated elasticity of external borrowing with respect to the tax rate is 0.20 , the estimated tax elasticity of borrowing from parent companies is 0.34 .

Second, the evidence indicates that external borrowing is more costly in environments in which creditor rights are weak and locally available external debt is scarce. Interest rates on external debt differ for affiliates of the same American parent company located in different host countries. Additionally, local capital market conditions and creditor rights do not appear to affect interest rates charged on related party debt further confirming this evidence.

Third, the composition of affiliate leverage responds to differences in local credit market conditions. Affiliates in countries with weak creditor rights and shallow capital markets substitute internal borrowing from parent companies for costly external debt. Instrumental variables regressions in which creditor rights and capital market conditions serve as instruments for the price or quantity of external debt indicate that affiliates increase related party borrowing by between half and three-quarters of the reduction in external borrowing due to capital market conditions. All of these results control for other considerations, such as the desire to hedge political risks and the inflationary environment, that also appear to influence affiliate leverage and its composition. In particular, multinational firms employ more local borrowing in response to higher inflation levels and greater political risk. 
Section 2 of the paper reviews studies of the effect of tax incentives on capital structure, the impact of local capital market conditions on financing decisions, and the workings of internal capital markets. Section 3 describes the affiliate-level data and offers summaries of the leverage and interest rate measures used in the analysis. Section 4 analyzes the determinants of affiliate capital structure and the use of internal capital to substitute for external sources of funds. Section 5 concludes.

\section{Motivation and Hypotheses}

The financing of foreign affiliates is likely to be influenced by the effect of local tax rates and capital market conditions on the after-tax cost of funds, conditioned on the ability to obtain resources from parent companies. As a result, affiliate financing illuminates the importance of taxes in influencing capital structure, the impact of institutions on financing choices, and the workings of internal capital markets.

\subsection{Taxes and Capital Structure}

Since interest payments to lenders usually are fully deductible from taxable income, while dividend payments to shareholders are not, tax systems typically encourage the use of debt rather than equity finance. ${ }^{1}$ This incentive grows as the corporate tax rate rises, so high corporate tax rates are often expected to be associated with greater corporate indebtedness. As Auerbach (2002) and Graham (forthcoming) note, however, estimating the sensitivity of capital structure to tax incentives has proven remarkably difficult, due in part to measurement problems. ${ }^{2}$ Consequently, it is not surprising that several studies find no effect or unexpected relationships between tax incentives and the use of debt. ${ }^{3}$ One problem in

\footnotetext{
${ }^{1}$ There are subtle differences between the tax incentives of domestic and multinational firms. American multinational firms owe taxes to the United States on their foreign incomes, but defer U.S. taxes until profits are repatriated, and are entitled to claim credits for foreign income taxes paid. The upshot of this system is that American firms typically can arrange their finances to benefit from the deductibility of interest expenses in hightax countries, much as do domestic firms in those countries; for analyses see Hines and Rice (1994) and Hines (1999).

${ }^{2}$ The Auerbach and Graham surveys provide exhaustive literature reviews that are beyond the scope of this section. In particular, valuation effects of debt usage, as analyzed by Fama and French (1998) and Graham (2000), are not considered, given the difficulty of identifying valuation changes attributable to individual foreign affiliates.

${ }^{3}$ These results have also generated considerable skepticism on the importance of taxes to capital structure as evidenced in Myers et al. (1998). Such skepticism does not conform to the survey results in Graham and Harvey (2001).
} 
identifying tax effects stems from the lack of variation in corporate tax rates. By focusing on whether a firm is near tax exhaustion, Mackie-Mason (1990) avoids this constraint and identifies evidence of tax effects, in which the deductibility of interest expenses appears to encourage firms to use greater leverage than they otherwise would. Graham (1996), Graham, Lemmon, and Schallheim (1998), and Graham (1999) employ a sophisticated measure of the marginal tax rate in the United States based on simulations and prevailing tax rules to investigate further the use of debt and the relevance of personal taxation. The use of cross-country evidence has the potential to contribute further evidence by analyzing outcomes when firms simultaneously select capital structures in several tax environments. This approach is able to overcome some of the difficulties that arise in identifying the marginal investor in general equilibrium, and in accounting for the numerous factors that might give rise to deviations from a Miller (1977) equilibrium.

Hodder and Senbet (1990) extend the logic of a Miller equilibrium to an international setting to suggest that, in an integrated world capital market, all firms will locate debt in the most tax-advantaged jurisdictions. ${ }^{4}$ As it is reasonable to posit that multinational firms operate in integrated capital markets, a multinational firm faces a single cost of capital, and therefore the relative tax advantage of debt in any market is simply a function of local tax rates. As a result, the sensitivity of foreign affiliate capital structure to foreign tax rates offers a powerful and clean test of the response of leverage to differential tax advantages to debt. $^{5}$

\subsection{Institutions, Markets and External Borrowing Conditions}

\footnotetext{
${ }^{4}$ While Hodder and Senbet (1991) predict extreme outcomes, there are other factors (some of which are considered below) that might constrain firms from corner solutions. Some countries impose "thin capitalization" rules that limit the tax deductibility of interest paid by firms deemed to have excessive debt. These rules are typically vaguely worded and seldom, though arbitrarily, imposed, making their effects difficult to analyze quantitatively; though any impact they have is likely to reduce the estimated significance of factors influencing total indebtedness. Also, "thin capitalization" rules generally do not affect the choice between different kinds of debt. Other theoretical examinations of the effect of tax incentives on the use of debt within multinational firms include Hines (1994), Chowdry and Nanda (1994), and Chowdry and Coval (1998).

5 Other studies examine specific aspects of the effect of taxation on the financing of multinational firms. See Froot and Hines (1995) on the effects of limits to the deductibility of interest expenses due to the U.S. allocation rules, Desai and Hines (1999) on changes in joint venture capital structure in response to foreign tax credit limitations, and Altshuler and Grubert (2003) on interaffiliate transactions motivated by tax rules.
} 
A large body of work indicates that there are important differences in the ability of firms to raise capital in different countries. LaPorta, Lopez-de-Silanes, Shleifer and Vishny (1998) trace these effects to differences in legal regimes, and create an index of creditor rights in bankruptcy for a large sample of countries. In prior work (1997), these authors show that these legal regimes have large effects on the size and breadth of capital markets: countries with weak creditor rights have significantly smaller local debt markets. There is evidence of other important determinants of financial development, but the empirical observation that financial development varies widely is commonly noted. ${ }^{6}$

Weak local financial markets appear to be associated with lower rates of investment and economic expansion. Evidence of this effect is provided at the country level by King and Levine (1993), at the industry level by Rajan and Zingales (1998), and at the firm level by Demirguc-Kunt and Maksimovic (1998). However, existing work does not detail the extent to which weak capital market conditions affect the cost of external borrowing, capital structure choice, and the use of internal capital markets as substitutes for external capital markets. In their cross-country analysis of the determinants of capital structure choice, Rajan and Zingales (1995) focus on G-7 countries, finding limited evidence of systematic differences across these similar countries. Booth, Aivazian, Demirguc-Kunt, and Maksimovic (2001) analyze firms in ten developing countries, finding that these firms use less long term debt than do comparable firms in developed countries, and that unspecified country factors are significant determinants of capital structure. These studies leave open questions of how capital market conditions might directly alter the cost of external debt, or how these conditions might push firms to attempt to substitute for locally provided external capital.

In order for multinational affiliate capital structure decisions to illuminate the mechanisms by which local contracting conditions impact borrowing costs, multinational bankruptcies must follow local bankruptcy rules rather than the bankruptcy rules of the home country. This is generally the case. As in international taxation, the two competing principles of "universality" and "territoriality" govern the issue of how transnational bankruptcies are resolved. Under universality, the jurisdiction where the primary

\footnotetext{
${ }^{6}$ See, for example, Rajan and Zingales (forthcoming).
} 
bankruptcy proceeding takes place would govern the assets and competing claims on those assets wherever they are located. In contrast, territoriality asserts that bankruptcy laws should not be respected beyond a state's borders.

As one might expect, states attempt to apply their laws to creditors and assets in other states, but severely limit the application of foreign bankruptcy laws to cases involving local creditors and local assets of a foreign debtor. Bebchuk and Guzman (1999) note that while U.S. bankruptcy law clearly extends jurisdiction of the bankruptcy court and the estate created by the filing of a bankruptcy proceeding to all assets worldwide, U.S. courts often are unwilling to relinquish control over domestic assets to foreign bankruptcy proceedings. The bankruptcy laws of many other countries are even more territorial in nature. Japanese bankruptcy law clearly states that bankruptcy rulings in other countries are not effective in Japan. Few bilateral bankruptcy treaties exist so any inconsistencies must rely on ad hoc cooperation arrangements, which have not worked well. ${ }^{7}$ Recent multilateral efforts “preserves to each state its local substantive law with respect to claims to the debtor's assets located in that state." ${ }^{\prime 8}$ In short, there is a remarkable void in the laws governing multinational bankruptcies, and the respect for territoriality suggests that local bankruptcy rules would apply to the resolution of insolvency proceedings involving a multinational affiliate. $^{9}$

As a result of the prevalence of territoriality, a multinational firm effectively is faced with the opportunity of borrowing across a variety of creditor rights regimes. Real borrowing rates should be higher (all other things equal) in countries in which lenders have fewer rights in the event of default. Noe (2000) provides an equilibrium model of capital

\footnotetext{
${ }^{7}$ See Tagashira (1994) for further discussion of these kinds of efforts.

${ }^{8}$ Gitlin and Flaschen (1987) describe the substance of the 1980 Working Group Draft of the EEC which has yet not been finalized. Section 304 of the U.S. bankruptcy code is unique in its recognition of foreign bankruptcy proceedings although ambiguous in respect to how it should be implemented. Powers (1993) details a more recent private effort to implement universality internationally.

${ }^{9}$ See, for example, Gitlin and Flaschen (1987). The messy resolution of the 1974 bankruptcy of the Herstatt Bank bankruptcy was due in part to the prevailing confusion on these jurisdictional issues. For a more recent example, see Flaschen and Silverman (1993) for a discussion of the Maxwell Communications Corporation (MCC) insolvency. The jurisdictional "shopping" involved in the MCC case provides an interesting example of the sensitivity of debtors to the biases of different legal codes. According to Flaschen and Silverman, after defaulting, "MCC became concerned that banks might seek the commencement of insolvency proceedings in England, which would effectively displace operating management. In response, MCC ... filed a voluntary petition under Chapter 11 of the United States Bankruptcy Court.”
} 
structure choice for multinational affiliates facing different legal regimes. ${ }^{10}$ The ability to renegotiate strategically with creditors in times of fiscal distress is attractive to the distressed firm but reduces its incentive to avoid bankruptcy, creating an agency problem that is reflected in higher borrowing rates.

Since shareholders bear agency costs, they want to minimize renegotiation opportunities, and do so by concentrating their borrowing in creditor-friendly environments while avoiding less-creditor-friendly environments. Moreover, internal capital markets can be used to fund subsidiaries in weak-creditor rights environments with loans from subsidiaries (or home operations) in strong-creditor-rights regimes. The analysis that follows tests for the effects of different creditor regimes to see if multinationals capitalize their affiliates and structure their internal financing in response to these regime differences. In addition to these predictions on the level and composition of affiliate debt, the interest rates paid by multinational firms should reflect the fact that lenders in countries with weak legal protections receive less in adverse states of the world than do lenders in countries providing strong legal protections. Furthermore, since there is adverse selection in the lending market, and moral hazard once borrowers receive loans, local banks and other lenders need to expend resources to investigate potential borrowers, monitor their behavior once loans are granted, and deploy legal resources to enforce contracts. These are real resource costs that should be reflected in still higher interest rates paid by borrowers and received by lenders in countries with weak creditor rights.

\subsection{Internal Capital Markets}

The sensitivity of investment to internal cash flows noted since Meyer and Kuh (1957) has drawn attention to the role of internal capital markets and how they are used by firms in response to any differences between internal and external costs of funds. Many efforts to examine the role of internal capital markets have been limited by relatively small samples, as in Blanchard, Lopez-de-Silanes, and Shleifer (1994) and Lamont (1997), or, as

\footnotetext{
${ }^{10}$ Shleifer and Wolfenzon (2002) analyze the impact of creditor rights on a variety of economic outcomes in closed and open economies. They find that interest rates in closed economies react to the strength of investor rights, though since they assume that monitoring and enforcement costs are effectively incurred by borrowers, interest rates need not rise in settings with weak creditor rights. Their model does not provide for intermediate cases where multinational firms trade-off borrowing opportunities across legal regimes, as Noe (2000) does.
} 
noted by Kaplan and Zingales (1997), by questionable a priori assumptions about what characterizes firms that face sizable wedges between internal and external costs of funds. It is possible to address these concerns by focusing on a large sample of firms, by looking across environments where differences between internal and external costs of funds differ for systematic legal and capital market development reasons, and by directly analyzing the allocation of funds within firms in response to these incentives. ${ }^{11}$

Tests of the extent of substitution of internal capital for external capital across different borrowing environments reveal the degree to which multinational firms can use internal markets to overcome shortcomings associated with external credit market conditions. These tests also produce powerful additional evidence of whether weak local capital market conditions do indeed constrain local borrowers. If affiliates substitute parent provided debt for external debt where creditor rights are weak, and where locally provided debt is scarce or expensive, then the use of external debt must be a relatively unattractive option in those locations. If local firms rely primarily on local sources of debt, then their access to large internal capital markets may give multinational affiliates cost advantages over local firms. Additionally, if tax incentives are operative, then internal capital markets should be even more sensitive to local tax incentives than is arm's-length borrowing, providing a further test of the effect of taxes on financing choices.

\section{Multinational Affiliate Data}

The empirical work analyzes data collected by the Bureau of Economic Analysis (BEA) for its Benchmark Survey of U.S. Direct Investment Abroad in 1982, 1989, and 1994, which includes information on the financial and operating characteristics of U.S. firms operating abroad. As a result of confidentiality assurances and penalties for noncompliance, BEA believes that coverage is close to complete and levels of accuracy are high. ${ }^{12}$ The surveys ask reporters for details on each affiliates' income statement, balance sheet,

\footnotetext{
${ }^{11}$ Stein (1997), Shin and Stulz (1998), and Scharfstein and Stein (2000), among others, discuss how internal capital markets can either ameliorate or exacerbate other frictions. Hubbard and Palia (1999) emphasize empirically how conglomerates may use internal capital markets opportunistically in response to costly external financing.

${ }^{12}$ The International Investment and Trade in Services Survey Act governs the collection of the data and the Act ensures that "use of an individual company's data for tax, investigative, or regulatory purposes is prohibited." Willful noncompliance with the Act can result in penalties of up to $\$ 10,000$ or a prison term of one year.
} 
employment, and a variety of transactions between U.S. parents and their foreign affiliates. The foreign affiliate survey forms that U.S. multinational enterprises are required to complete vary depending on the year, the size of the affiliate, and the U.S. parent's percentage of ownership of the affiliate. In each of the benchmark years considered (1982, 1989, and 1994), all affiliates with sales, assets, or net income in excess of \$3 million in absolute value, and their parents, were required to file extensive reports. ${ }^{13}$ Reporters must abide by generally accepted U.S. accounting principles and follow FASB 52 when dealing with foreign currency translations. ${ }^{14}$

U.S. direct investment abroad is defined as the direct or indirect ownership or control by a single U.S. legal entity of at least ten percent of the voting securities of an incorporated foreign business enterprise or the equivalent interest in an unincorporated foreign business enterprise. A U.S. multinational entity is the combination of a single U.S. legal entity that has made the direct investment, called the U.S. parent, and at least one foreign business enterprise, called the foreign affiliate. ${ }^{15}$ In order to be considered as a legitimate foreign affiliate, the foreign business enterprise should be paying foreign income taxes, have a substantial physical presence abroad, keep separate financial records, and should take title to the goods it sells and receive revenue from its sales.

The top panel of Table I displays the descriptive statistics for the sample of affiliates in each of the three benchmark years. In 1994, 17,898 affiliates of 2,373 parent firms filed forms, and these affiliates had mean and median assets of \$74 million and \$13 million respectively. The main measure of leverage used in the analysis that follows is the ratio of current liabilities and long-term debt to affiliate assets. This measure has a mean and median of approximately 0.55 over the sample period. The main reason for focusing the analysis on this measure of leverage is that the data allow this measure to be disaggregated

\footnotetext{
${ }^{13}$ The particularities of the reporting vary with ownership form and size. Majority-owned affiliates were required to report a broader set of accounting items than minority-owned affiliates. Additionally, in 1989 and 1994 larger affiliates were required to file longer forms than were smaller affiliates.

${ }^{14}$ Additional information on the BEA data can be found in Mataloni (1995).

${ }^{15}$ In order to determine ownership stakes in the presence of indirect ownership, BEA determines the percentage of parent ownership at each link and then multiplies these percentages to compute the parent's total effective ownership.
} 
into the amount owed to an affiliate's corporate parent and the amount owed to other lenders.

As the data in Table I indicate, the vast majority of debt comes from non-parent sources. Net Current Liabilities and Long-Term Debt Owed to Parent/Assets is the ratio of the difference between the level of current liabilities and long term debt an affiliate borrows from, and lends to, its U.S. parent to total affiliate assets. This variable has a mean of approximately 0.08 over the sample period, and a median that is just larger than zero. Current Liabilities and Long-Term Debt Owed to Non-Parents/Assets, the ratio of the level of current liabilities and long term debt an affiliate borrows from non-parent sources to total affiliate assets, has a mean of 0.44 and a median of 0.41 for the benchmark years. On average less than 20 percent of current liabilities and long-term debt comes from parent sources. ${ }^{16}$

The BEA data also contain information on the interest expense associated with affiliate debt, and it is possible to use this information to calculate an affiliate's average interest rate in a year. Because the data do not contain detailed information on interest rates charged on individual loans or on which types of debt are interest bearing, the analysis uses two estimates of interest rates. The first measure is the Interest Rate on Non-Parent Liabilities and Debt, which is calculated by dividing affiliate interest payments to nonparents by current liabilities and long-term debt borrowed from non-parent sources. This variable has a mean of approximately 0.05 and a median of approximately 0.02 over the sample period. One of the reasons that these average interest rates appear low is that the broad measure of debt used in this calculation includes trade credit which is often noninterest bearing. ${ }^{17}$

\footnotetext{
${ }^{16}$ Two shortcomings of the data potentially limit identification of external and parent borrowing. First, there is no information on the extent to which parent companies guarantee affiliate loans. Second, back-to-back loans, in which a parent lends to a multinational bank which in turn lends to an affiliate through a branch located abroad, are recorded as external debt despite significant parent involvement. Unfortunately, there is no way of estimating the extent to which firms use parental guarantees or back-to-back loans. Since these shortcomings blur the distinction between external and parent borrowing, they may reduce the measured differences between these two forms of debt. As a result, tests that distinguish the responsiveness of external and parent debt to taxes and borrowing conditions using these data if anything underestimate true differences, and tests of the substitution of parent provided debt for external debt if anything underestimate the extent of substitution.

${ }^{17}$ Interest rates are based on current interest payments, and therefore exclude payments to creditors in the event of default. Capital market equilibrium implies that interest rates measured in this way should be higher in
} 
To ensure that the analysis of interest rates does not yield results that are spuriously driven by differences in the use of trade credit, the analysis also employs Interest Rate on Non-Trade Account Liabilities and Debt, which is the ratio of total interest paid to a measure of current liabilities and long term debt that excludes trade accounts and trade notes payable. This alternative interest rate variable has a mean of 0.08 and a median of 0.04 . Unlike the first interest rate variable, this measure combines both the interest expense associated with, and the level of, related party and arm's-length debt.

The bottom panel of Table I provides summary statistics for independent variables used in the regression analysis. Included among these variables are measures of affiliate characteristics that have been shown to be correlated with leverage in other studies. ${ }^{18}$ These are all drawn from BEA data and include a measure of the tangibility of affiliate assets (Net Property, Plant and Equipment/Assets), the cash flow generating capacity of underlying assets (EBITDA/Assets), and affiliate size (the natural logarithm of affiliate sales). In addition, the relevant country-level measures of tax incentives, capital market depth, legal protections, and macroeconomic and political stability are also summarized. The BEA data is also the source of the tax rate data. The country tax rate is calculated by first taking the ratio of foreign income taxes paid to foreign pretax income for each affiliate observation and then using the medians of these rates as country-level observations for each country and year. ${ }^{19}$ Mean and median country tax rates are equal to approximately 34 percent over the sample period. Private Credit is the ratio of private credit lent by deposit money banks to GDP, as provided in Beck, Demirguc-Kunt, and Levine (1999). Creditor Rights is an index of the strength of creditor rights developed in LaPorta, Lopez-de-Silanes, Shleifer, and Vishny (1998) that ranges from 0 to 4 with higher levels indicating stronger legal

jurisdictions in which creditor rights are weaker, and expected default payments are lower. Interest payments are recorded in U.S. dollars. The currency denomination of debt may be important to financial decision making within a multinational firm, but it is impossible to tell from the BEA data in which currency debt is formally denominated. See Kedia and Mazumdar (forthcoming) and Allayannis, Brown and Klapper (forthcoming) for analyses of the determinants of the currency denomination of debt.

${ }^{18}$ See, for example, Titman and Wessels (1988) and Rajan and Zingales (1995).

${ }^{19}$ Affiliates with negative net income are excluded for the purposes of calculating country tax rates. For a more comprehensive description of the calculation of affiliate tax rates, see Desai, Foley and Hines (2001). In particular, these income tax rates do not include withholding taxes on cross-border interest payments to related parties, since such taxes are endogenous to interest payments and in any case immediately creditable against home-country tax liabilities. Desai and Hines (1999) report that adjusting country tax rates for withholding taxes 
protections. Political Risk is an index of the average level of political risk over the 19821994 period derived from the International Country Risk Guide, rescaled to lie between 0 and 1, with higher values indicating greater risk. The Average Rate of Inflation is the average percentage change in the host country's GDP deflator over the 1982-1994 period.

\section{Results}

The regressions reported in this section investigate three aspects of borrowing by foreign affiliates: how total leverage is affected by local tax rates and legal protections available to creditors, how interest rates on related party and external debt are affected by legal protections and capital market depth, and how multinational firms use related party debt to substitute for external debt in cases in which government policies make external debt costly.

\subsection{Determinants of Affiliate Leverage}

Affiliates in countries with high local corporate tax rates face the strongest incentives to finance their investments with debt rather than equity. Prior to investigating the relationship between leverage and tax rates in a regression framework using countryspecific, firm-specific and affiliate-specific controls, it is useful to assess this relationship with aggregate data. Figure 1 depicts the relationship between country tax rates and U.S. affiliate leverage in 1994. Leverage is measured as the ratio of aggregate current liabilities and long term debt to aggregate assets in each host country as published in the 1994 benchmark survey. ${ }^{20}$ Figure 1 indicates that affiliates in high tax countries generally make greater use of debt to finance their assets than do affiliates in low tax countries. Affiliates in tax havens such as Bermuda and Barbados have aggregate leverage ratios of 0.30 or less, while affiliates in high tax countries such as Japan and Italy have aggregate leverage ratios that exceed 0.53. Although the scatter plot in Figure 1 does not control for characteristics of affiliates, or non-tax features of host countries, it does provide suggestive evidence that

\footnotetext{
does not affect the estimated impact of taxation on affiliate borrowing, due to the combination of creditability and low withholding tax rates on related-party interest payments.

${ }^{20}$ See U.S. Department of Commerce (1998). When countries are equal weighted the measure of leverage described in the text has a mean of 0.49 and a standard deviation of 0.13 .
} 
multinational parents capitalize their affiliates differentially in response to the incentives associated with the relative tax advantage of debt.

Figure 2 provides a similar descriptive scatter plot but emphasizes the relationship between capital market depth, measured as the ratio of private credit lent by deposit money banks in the host country to GDP, and aggregate leverage ratios of U.S. affiliates in 1994. The upward-sloping pattern in Figure 2 suggests that there is a positive correlation between levels of affiliate leverage and the local availability of credit. U.S. affiliates exhibit high leverage ratios in countries such as Japan and Switzerland, which have very deep credit markets, and considerably lower leverage ratios in countries such as Peru, the Dominican Republic, and Panama, where domestic private credit is scarce. There are exceptions to this pattern: affiliates have high leverage ratios in Honduras, Ecuador, Nigeria, Venezuela and some other countries in which they seem to overcome shortcomings in local credit markets. In order to isolate more carefully the relationship between affiliate leverage, corporate tax incentives, and the strength of local credit markets, while also controlling for conflating factors, it is helpful to run regressions, the results of which are presented in Table II.

The dependent variable in the specifications reported in Table II is the same measure of leverage employed in Figures 1 and 2, but is constructed at the affiliate level, so it equals the ratio of affiliate current liabilities and long term debt to total assets. The data consist of affiliate-year observations for affiliates of U.S. firms in 1982, 1989, and 1994. The regressions reported in columns 1 and 2 of Table II suggest that affiliate leverage responds strongly to local tax incentives. The 0.2508 estimated coefficient on the country tax rate in the regression reported in column 1 implies that ten percent higher tax rates are associated with affiliate leverage that is 2.5 percent greater as a fraction of assets. ${ }^{21}$ One difficulty with interpreting the tax rate coefficient reported in column 1 is that the specification does not control for other potential determinants of affiliate leverage, particularly those that vary between companies and over time. Column 2 of Table II reports estimated coefficients from a regression that includes a full set of year dummy variables, parent company dummy variables, and affiliate industry dummy variables. As a result, firm-specific considerations 
and industry-specific considerations implicitly do not affect the estimates reported in column 2 and subsequent specifications reported in even-numbered columns of Table II. The estimated effect of local tax incentives on affiliate leverage decisions is robust to the inclusion of fixed effects (the estimated tax rate coefficient reported in column 2 is almost identical to that reported in column 1), and to the inclusion of additional explanatory variables in columns 3 through 10 .

The specifications presented in columns 3 through 10 of Table II also consider the effect of capital market development and investor protections on levels of affiliate leverage. In column 3 , the estimated 0.0166 coefficient on private credit indicates that greater capital market depth, as captured by ten percent greater use of private credit as a fraction of GDP, corresponds to 0.166 percent greater affiliate leverage as a fraction of assets. This effect disappears, however, when parent, industry and year fixed effects are included, as in the regression presented in column 4. The regressions reported in columns 5 and 6 indicate that stronger legal protections for creditors are associated with greater use of debt, and this effect is robust to the inclusion of parent, industry, and year fixed effects. In the regression reported in column 6, a one-point increase in the (5-point) creditor rights index is associated with 0.82 percent higher affiliate leverage ratios.

These regressions may in part reflect the impact of heterogeneous affiliate and country characteristics that are unrelated to tax rates and creditor rights, but happen to be correlated with them. It is possible to control for relevant observable aspects of heterogeneity, such as the tangibility of affiliate assets, the cash flow generating capacity of underlying assets, affiliate size, the political risk of the country of the affiliate, and the average inflation experience of the affiliate's host country. The regressions reported in columns 7-10 of Table II add these variables to the specifications reported in columns 3-6. Since affiliate characteristics are potentially endogenous to the tax and legal environment, the purpose of including these variables is to see whether controlling for heterogeneity with their inclusion greatly changes the estimated impact of tax rates and legal protections for creditors. The sample size in these specifications is significantly smaller because

\footnotetext{
${ }^{21}$ Standard errors are in parentheses. The regression is based on treating each affiliate-year observation in the panel as a separate observation; the standard errors in all of the tables correct for clustering of errors across
} 
information required to construct the additional controls is collected only for a smaller set of affiliates. $^{22}$

These other affiliate and country characteristics appear to also influence leverage ratios. Affiliates with greater shares of assets in tangible property use less debt, although the significance of this effect is sharply reduced with the inclusion of parent, industry and year effects. Affiliates characterized by greater cash flow generating capacity have significantly lower levels of affiliate leverage. While a country's average inflation rate over the period has no significant effect on affiliate leverage, multinational parents appear to employ greater levels of leverage in more politically risky countries. ${ }^{23}$ These controls suggest that leverage may be used to hedge political risks, and that borrowing needs are limited by the capacity for producing internally generated funds. The inclusion of these additional affiliate and country variables has little effect on the estimated impact of taxation and creditor rights on affiliate leverage.

\subsection{Determinants of Interest Rates}

Tax policies and local capital market conditions influence leverage by affecting after-tax borrowing costs. It is possible to examine these effects directly, by identifying the impact of capital market conditions on pretax interest rates. One of the attractive aspects of performing such an investigation using a panel of multinational affiliates is that it is possible to compare interest rates faced by affiliates of the same parent firms in different countries.

Table III presents regressions in which the dependent variable is the Interest Rate on Non-Parent Liabilities and Debt. The regressions reported in the even-numbered columns of Table III include parent, country, and year fixed effects, and all of the reported standard errors allow for clustering at the country/industry level. Since only certain affiliates are

observations in country/industry cells.

${ }^{22}$ Specifically, all majority owned affiliates that report in 1982, and all majority owned affiliates that are large enough to file the long form in 1989 and 1994 are included in the reduced sample. The sample size changes in similar ways in Tables V, VI, VIII, and A1.

${ }^{23}$ These results on political risk are consistent with Novaes (2002) who demonstrates that foreign affiliates in Brazil are more highly levered than local firms, and alter their leverage in response to political risk. 
required to report certain items, the sample used in these specifications is the smaller sample used in the regressions presented in columns $7-10$ of Table II. ${ }^{24}$

The regressions reported in columns 1-4 of Table III measure the interest rate impact of capital market depth and creditor rights protection. The estimated -0.0443 coefficient reported in column 1 indicates that ten percent greater host country use of private credit as a fraction of GDP is associated with 0.4 percent lower interest rates. The regression reported in column 2 shows that this effect persists when controlling for parent, industry, and year fixed effects. The results presented in columns 3 and 4 suggest that stronger legal protections for creditors reduce interest rates, a one-point improvement in legal protections being associated with one percent lower interest rates. Columns 5-8 report regressions that are the same as those reported in columns 1-4, but add controls for local tax rates, affiliate level variation in tangibility of assets, cash-flow generating capacity, and size and countrylevel variation in political risk and inflation. Better creditor rights and private credit availability continue to be associated with lower interest rates, though the magnitudes of the estimated effects are smaller in these regressions than in the corresponding regressions reported in columns 1-4. Affiliates with greater earnings as a fraction of assets face lower borrowing rates, as do affiliates with fewer tangible assets; higher levels of political risk and inflation appear to increase local borrowing rates.

The regressions presented in Table III indicate that interest rates are higher in countries with underdeveloped capital markets and poor creditor legal rights. It is noteworthy that, since parent company fixed effects are included as independent variables in the regressions reported in the even-numbered columns of Table III, these interest rate effects appear between affiliates of the same companies. This evidence is, however, subject to two limitations. The first is that the denominator of the interest rate variable is total liabilities, including trade credits on which explicit interest is seldom paid. As a result, measured interest rates are somewhat low and may vary between countries due to trade financing practices. The second limitation is that related-party and third-party debt are treated symmetrically, which while statistically appropriate nonetheless obscures what might be an important distinction. Since creditor rights are considerably less important for

\footnotetext{
${ }^{24}$ This same sample is also used in the specifications reported in Tables IV and VII.
} 
intrafirm contracting than they are for contracts between unrelated parties, it follows that the interest rate effects of creditor rights (or capital market development) should be much smaller in the case of related party debt.

Table IV reports estimated coefficients from regressions designed to address these issues. The dependent variable is again the interest rate, in this case constructed as the ratio of total affiliate interest payments to other current liabilities and long-term debt, excluding trade accounts. The estimated capital market effects obtained using this dependent variable, reported in columns 1-4 of Table IV, have the same signs and smaller magnitudes than those obtained using the first interest rate variable and reported in columns 1-4 of Table III. Thus, the -0.0049 estimated coefficient in column 4 of Table IV indicates that a one-point improvement in creditor rights is associated with 0.49 percent lower interest rates, or somewhat greater than half the effect estimated using the other interest rate variable.

Some care is necessary in order to identify differences in interest rates charged by parent companies and interest rates charged by all other parties, since the data do not distinguish trade credits from other sources of parent debt for all years. Columns 5-8 of Table IV present regressions using the same dependent variable as in the regressions reported in columns 1-4, but adding two independent variables: the share of debt from nonparent sources, ${ }^{25}$ and the interaction between this share and measures of capital market development or creditor rights. The results indicate that greater borrowing from non-parent sources is associated with higher interest rates, ${ }^{26}$ and this effect is strongest where capital markets are least developed or creditor rights are weakest. For example, the 0.0232 coefficient on the share of debt from non-parent sources reported in column 8 indicates that external debt carries 2.32 percent higher interest rates than internal debt in countries with creditor rights indices of zero. The -0.0078 coefficient on the interaction of creditor rights and non-parent debt share in the same column implies that the interest rate effect of borrowing from non-parents declines as creditor rights strengthen, disappearing at a creditor

\footnotetext{
${ }^{25}$ The share of debt from non-parent sources equals one minus the ratio of current liabilities and long-term debt owed to the parent to total current liabilities and long-term debt.

${ }^{26}$ The estimated coefficients imply that greater use of non-parent debt increases interest rates at mean values of the credit market and creditor rights variables, though not at all possible values.
} 
rights index level of 3 (which greatly exceeds its mean value of 2). ${ }^{27}$ It is noteworthy that the estimated effects of capital market development and creditor rights not interacted with the share of non-parent debt do not differ significantly from zero in the equations reported in columns 5-8, suggesting that parent debt is no more expensive due to these capital market considerations.

\subsection{The Composition of Affiliate Leverage}

The finding that costs of external borrowing are particularly high where private credit is scarce and creditor rights are weak raises the question of whether affiliates avoid the use of external funds in these environments by relying on internal capital markets to a greater extent. Figure 3 displays the relationship between the depth of local credit markets and aggregate borrowing from non-parent sources. The scatter plot implies a positive relationship between capital market depth and external borrowing. Comparing Figure 2 to Figure 3 suggests that borrowing from non-parent sources is more sensitive to local capital market conditions than is total leverage. Affiliates located in many of the countries with weak credit markets, such as Honduras, Ecuador, Guatemala, Argentina, and Venezuela, rely heavily on their parents for debt.

Figure 4 offers additional evidence of the effect of the borrowing environment on the composition of debt by graphing the relationship between creditor rights and different types of debt. There is a subtle rise in the ratio of total current liabilities and long term debt to assets as the creditor rights index increases from zero to four. However, this aggregate measure obscures divergent effects of creditor rights on borrowing from parents and borrowing from non-parent sources. The ratio of net parent borrowing to assets decreases as creditor rights improve, while the ratio of aggregate arms length borrowing to aggregate assets increases as creditor rights improve.

In order to analyze these divergent effects more rigorously, Table $\mathrm{V}$ presents regressions that evaluate the impact of tax incentives and measures of capital market depth

\footnotetext{
${ }^{27}$ It is unlikely that external debt actually becomes less expensive than parent debt in countries with creditor rights indices above 3; this anomalous prediction instead stems from the imposed linearity of the regression equation, while the true relationship may be nonlinear.
} 
on net borrowing from parent companies; Table VI presents comparable regressions in which the dependent variable is external borrowing. In the regressions reported in Table V, the dependent variable is the ratio of net current liabilities and long term debt owed to parents to total affiliate assets. Parent companies use more debt in high tax rate environments, as evidenced by the positive estimated coefficients on the country tax rate variable in Table $\mathrm{V}$, and this effect is robust to the inclusion of parent, industry and year effects as well as affiliate and country level control variables. The 0.0805 estimated tax rate coefficient in the regression reported in column 8 of Table $\mathrm{V}$, together with a sample mean parent debt to assets ratio of 0.0801 , and a sample mean tax rate of 0.3431 , implies a tax elasticity of parent borrowing equal to $0.34 .^{28}$ While the estimated 0.2577 tax rate coefficient in the external borrowing regression reported in column 8 of Table VI is significantly larger, the implied elasticity of external borrowing is only 0.20 , reflecting the much larger mean volume of external borrowing. ${ }^{29}$ The greater tax rate sensitivity of internal borrowing than external borrowing is consistent with the ability of multinational firms to fine-tune their internal financial transactions to avoid taxes.

Capital market depth and creditor rights have sharply differing effects on parent borrowing and external borrowing. The results presented in Table V indicate that greater availability of private credit and stronger creditor rights are associated with significantly reduced borrowing from parents; these effects are robust to the inclusion of parent, industry and year effects, and persist with the inclusion of affiliate and country level controls. For example, the -0.0037 estimated coefficient in column 10 of Table $\mathrm{V}$ implies that a one unit increase in the creditor rights index is associated with borrowing from parents that falls by 0.4 percent of total assets. Exactly the opposite pattern appears for external borrowing, as indicated by the results appearing in Table VI, where arm's-length borrowing increases in deeper capital markets and in markets that provide for better creditor protections. For example, the 0.0075 estimated coefficient in column 10 of Table VI indicates that a one unit increase in the creditor rights index raises borrowing from external sources by 0.75 percent

\footnotetext{
${ }^{28} 0.0805 *(0.3431 / 0.0801)=0.34$.

${ }^{29}$ The sample mean ratio of borrowing from non-parents to total assets is 0.4439 , and $0.2577 *(0.3431 / 0.4439)=$ 0.20 .
} 
of assets. Thus, it appears that the aggregate effects considered in Table II mask distinct and contrary effects of capital market indicators on the components of borrowing.

\subsection{The Substitutability of External and Internal Funds}

The fact that multinational affiliates use less external debt and more related-party debt in settings in which capital market conditions make external debt expensive is consistent with the hypothesized effects but does not fully measure the degree to which these alternative forms of financing serve as substitutes. The regressions presented in Table VII make these comparisons more explicit in a first effort to identify the degree of substitutability between parent and external debt. The left panel (first four columns) of Table VII presents regressions in which the dependent variable is borrowing from nonparent lenders, while the right panel (columns 5-8) presents regressions in which the dependent variable is borrowing from parents. The independent variable of most interest in these regressions is the interest rate paid on non-parent debt. Columns 3-4 and 7-8 report estimated coefficients from instrumental variable (IV) regressions in which capital market variables are used as instruments for these interest rates. The advantage of specifying these equations as IV regressions is that doing so makes it possible to trace the effect of capital market conditions on the cost of external borrowing and its subsequent impact on internal and external leverage.

The results indicate that borrowing is highly responsive to policy-induced interest rate differences. The OLS regressions reported in columns 1-2 of Table VII show little impact of interest rates on external borrowing, but this is neither surprising nor particularly informative, given the potential endogeneity of interest rates to borrowing levels. The IV results reported in columns 3 and 7 indicate that multinational firms reduce external borrowing and increase parent borrowing in response to the increase in local interest rates driven by reduced capital market depth. One percent higher interest rates due to capital market underdevelopment are associated with 2.0 percent reduced external borrowing, and 1.4 percent greater parent borrowing, as a fraction of total assets. The use of creditor rights as an instrument in the regressions reported in columns 4 and 8 produces somewhat smaller, but otherwise similar, results. In these regressions, one percent higher interest rates due to 
poor creditor rights are associated with 1.5 percent reduced external borrowing, and 0.6 percent greater parent borrowing, as a fraction of total assets. The smaller estimated magnitude of the interest rate effect on parent borrowing implies that substitution of parent for external debt, while considerable, is incomplete - which is consistent with the effects of capital market conditions on total borrowing reported in Table II.

Estimated coefficients on control variables included in the regressions reported in Table VII are consistent with the substitutability of parent and external debt. While other variables have coefficients of the same sign in the regressions for parent and external borrowing, multinational parents are particularly likely to lend to smaller affiliates (as measured by sales) that may have difficulty borrowing locally. Similarly, affiliates borrow more from unrelated parties in high-inflation countries, and reduce parent borrowing. Assuming that arms-length debt is more likely denominated in local currencies, greater external borrowing and reduced parent borrowing in high inflation countries is consistent with hedging inflation risk through greater local borrowing. Similarly, the positive estimated coefficients on the political risk index in the IV regressions presented in column 6 suggests that political risk is hedged by multinational firms through greater borrowing externally and substitution of parent debt for equity.

The extent to which firms substitute parent debt for external debt can be measured directly, and that is purpose of the regressions reported in Table VIII, in which parent debt is the dependent variable and arm's-length debt is an independent variable. In this setting a coefficient of -1.0 on arm's-length debt would correspond to perfect substitutability between parent and arm's-length debt. Since external and arm's-length debt are jointly determined, it is important to use capital market depth and the creditor rights index as instruments for levels of arm's-length debt; these IV regressions are reported in columns 3-4 and 7-8 of Table VIII.

The -0.9693 coefficient reported in column 3 of Table VIII implies that parent debt substitutes almost perfectly for arm's-length debt. This estimated degree of substitution comes from using the extent of capital market development as an instrument for arm'slength interest rates, and is somewhat smaller (though still statistically indistinguishable 
from unity) once affiliate and country controls are included, as in the regression reported in column 7. Using the creditor rights variable as an alternative instrument produces an estimated coefficient closer to -0.5 in the regressions reported in columns 4 and 8 , which corresponds to partial substitutability, in which parent lending makes up for half of any debt reduction due to higher interest rates. All of the specifications imply significant substitutability of parent borrowing for external borrowing in response to cost differences driven by local economic policies. By implication, local firms not affiliated with multinational parent companies face significantly higher costs of capital.

Given that the measures of parent and external debt used in the regressions reported in Table VIII are normalized by assets, and debt levels are highly correlated with total assets, it is conceivable that the measured substitutability of parent for arm's-length debt might simply be a function of the way in which the variables are constructed. For example, if all assets were financed with debt (which is not the case), then the sum of the parent debt ratio and the arm's-length debt ratio would equal one, and the estimated coefficient in an OLS regression of parent debt on arm's-length debt would be -1 . This is unlikely to be a problem for the IV estimates, which exploit only the part of the variation in arm's-length debt that is attributable to capital market considerations, but it is nevertheless useful to consider alternative specifications for which the concern would not arise even in an OLS setting. Appendix Table I presents regressions using the same specifications as those presented in Table VIII, with the difference that the parent and arm's-length debt measures are normalized by affiliate owners' equity instead of affiliate assets. The results are consistent with those reported in Table VIII, suggesting that the measured substitutability of parent for arm's-length debt in the regressions reported in Table VIII is not the product of the way in which the variables are constructed.

\section{Conclusions}

Understanding the causes and consequences of differences between external and internal costs of finance - whether they arise from informational asymmetries, government policies, poor contracting environments, or agency problems - is an important agenda in finance. While theory illuminates many possible responses of capital structure to cost 
differences, the empirical literature has struggled with the absence of institutional variation to study these determinants of financing choices. Even identifying the responsiveness of firms to the tax advantage of debt has proven challenging, much of the best evidence coming from subtle differences introduced by firms transiting between taxable and tax-loss status. One of the advantages of examining these issues across countries is that doing so permits the use of rich variation in tax rates and government policies. The common difficulty that crosscountry studies encounter in comparing the behavior of heterogeneous firms whose actions are measured using very different accounting conventions is greatly attenuated by the analysis of within-parent firm variation in the financing choices of U.S. multinational firms operating in countries with varied tax incentives and capital market conditions.

Certain patterns appear consistently in the results. Affiliates in countries with underdeveloped capital markets and weak creditor protections face higher interest rates on arm's-length borrowing than do affiliates in other countries. Firms respond to higher interest rates by borrowing less from external sources and more from parent companies, on net reducing the total amount that they borrow as a fraction of assets, since parent lending replaces between one half and three quarters of the reduction in external borrowing. Higher tax rates increase the use of debt from all sources, with related party borrowing exhibiting greater responsiveness to tax rate differences than does arm's-length borrowing.

These findings not only offer evidence of the tax and capital market determinants of capital structure, but also illustrate factors influencing the choice between external and internal finance. While the centrality of internal finance to investment is widelyappreciated, the allocation of funding within a firm is not well understood. This paper examines the ways in which firms use internal capital markets opportunistically to complement external financing opportunities when external finance is costly and when there are tax arbitrage opportunities.

These results also suggest that multinationals have significant advantages, as a result of their internal capital markets, over local firms that are constrained by local contracting 
environments. ${ }^{30}$ The combination of lower affiliate leverage, greater affiliate borrowing from parents, and substitution between internal funds and external funds indicates that countries with shallower capital markets and weak creditor rights offer multinational firms advantages relative to local firms that are less able to access global capital markets.

\footnotetext{
${ }^{30}$ In a related vein, Desai, Foley and Hines (2003) find that multinational firms respond to capital controls through transfer pricing and altered dividend policies. This ability to circumvent capital controls and to access global capital markets appears to provide multinational firms with advantages relative to local firms in countries with capital controls.
} 


\section{References}

Allayannis, George, Gregory W. Brown and Leora F. Klapper (forthcoming), "Capital Structure and Financial Risk: Evidence from Foreign Debt Use in East Asia," Journal of Finance.

Altshuler, Rosanne and Harry Grubert (2003), "Repatriation Taxes, Repatriation Strategies and Multinational Financial Policy," Journal of Public Economics, 87:73107.

Auerbach, Alan (2002), "Taxation and Corporate Financial Policy," in Alan Auerbach and Martin Feldstein (eds.) Handbook of Public Economics Volume III, 1251-1292.

Bebchuck, Lucian Ayre and Andrew T. Guzman (1999), “An Economic Analysis of Transnational Bankruptcies," Journal of Law and Economics, 42:775-806.

Beck, Thorsten, Asli Demirguc-Kunt and Ross Levine (1999), "A New Database on Financial Development and Structure," mimeo.

Blanchard, Olivier, Florencio Lopez-de-Silanes and Andrei Shleifer (1994), "What Do Firms Do with Cash Windfalls?," Journal of Financial Economics, 36:337-360.

Booth, Laurence, Varouj Aivazian, Asli Demirguc-Kunt and Vojislav Maksimovic (2001), "Capital Structures in Developing Countries," Journal of Finance, 56:87-130.

Chowdry, Bhagwan and Vikram Nanda (1994) "Internal Financing of Multinational Subsidiaries: Parent Debt vs. External Debt," Journal of Corporate Finance, 1:259281.

Chowdry, Bhagwan and Josh Coval (1998), "Internal Financing of Multinational Subsidiaries: Debt vs. Equity,” Journal of Corporate Finance, 4:87-106.

Demirguc-Kunt, Asli and Vojislav Maksimovic (1998), “Law, Finance, and Firm Growth," Journal of Finance, 53:2107-2137.

Desai, Mihir A. and James R. Hines Jr. (1999), "'Basket Cases': Tax Incentives and International Joint Venture Participation by American Multinational Firms," Journal of Public Economics, 71:379-402.

Desai, Mihir A., C. Fritz Foley and James R. Hines Jr. (2001), "Repatriation Taxes and Dividend Distortions," National Tax Journal, 54:829-851.

Desai, Mihir A., C. Fritz Foley and James R. Hines Jr. (2003), "Capital Controls, Liberalization and Foreign Direct Investment," Harvard University Working Paper.

Fama, Eugene F. and Kenneth R. French (1998), “Taxes, Financing Decisions and Firm Value," Journal of Finance, 53:819-843. 
Flaschen, Evan D. and Ronald J. Silverman (1993), "Maxwell Communication Corporation plc: The Importance of Comity and Cooperation in Resolving International Insolvencies," in Multinational Commercial Insolvency, American Bar Association.

Froot, Kenneth A. and James R. Hines, Jr. (1995), "Interest Allocation Rules, Financing Patterns, and the Operations of U.S. Multinationals," in Martin Feldstein, James R. Hines, Jr. and R. Glenn Hubbard (eds.), The Effect of Taxation on Multinational Corporations, Chicago: University of Chicago Press.

Gitlin, Richard A. and Evan D. Flaschen (1987), "The International Void in the Law of Multinational Bankruptcies," Business Law, 42:307-323.

Graham, John R. (1996), "Debt and the Marginal Tax Rate," Journal of Financial Economics, 41:41-73.

Graham, John R. (1999), "Do Personal Taxes Affect Corporate Financing Decisions?," Journal of Public Economics, 73:147-185.

Graham, John R. (2000), "How Big are the Tax Benefits of Debt?," Journal of Finance, 55:1901-1941.

Graham, John R. (forthcoming), “Taxes and Corporate Finance: A Review," Review of Financial Studies.

Graham, John R. and Campbell Harvey (2001), "The Theory and Practice of Corporate Finance: Evidence from the Field," Journal of Financial Economics, 60:187-243.

Graham, John R., Michael Lemmon and James S. Schallheim (1998), "Debt, Leases, Taxes and the Endogeneity of Corporate Tax Status," Journal of Finance, 53:131162.

Hines, James R., Jr. (1994), "Credit and Deferral as International Investment Incentives," Journal of Public Economics, 55:323-347.

Hines, James R., Jr. (1999), “Lessons from Behavioral Responses to International Taxation," National Tax Journal, 52:305-322.

Hines, James R., Jr. and Eric M. Rice (1994), "Fiscal Paradise: Foreign Tax Havens and American Business," Quarterly Journal of Economics, 109:149-182.

Hodder, James and Lemma Senbet (1990), "International Capital Structure Equilibrium," Journal of Finance, 45:1495-1517.

Hubbard, R. Glenn and Darius Palia (1999), "A Reexamination of the Conglomerate Merger Wave in the 1960s: An Internal Capital Markets View," Journal of Finance, $54: 1131-1152$. 
Kaplan, Steven and Luigi Zingales (1997), "Do Investment-Cashflow Sensitivities Provide Useful Measures of Financing Constraints?," Quarterly Journal of Economics, 112:169-216

Kedia, Simi and Abon Mozumdar (forthcoming), "Foreign Currency Denominated Debt: An Empirical Examination," Journal of Business.

King, Robert G. and Ross Levine (1993), "Finance and Growth: Schumpeter Might Be Right," Quarterly Journal of Economics, 108:713-737.

La Porta, Rafael, Florencio Lopez-de-Silanes, Andrei Shleifer and Robert Vishny (1997), "Legal Determinants of External Finance," Journal of Finance, 52:1131-1155.

La Porta, Rafael, Florencio Lopez-de-Silanes, Andrei Shleifer and Robert Vishny (1998), "Law and Finance," Journal of Political Economy, 106:1113-1155

Lamont, Owen (1997), "Cash Flow and Investment: Evidence from Internal Capital Markets," Journal of Finance, 52:83-109

Mackie-Mason, Jeffrey (1990), "Do Taxes Affect Corporate Financing Decisions?," Journal of Finance, 45:1471-1493.

Mataloni, Raymond (1995), “A Guide to BEA Statistics on U.S. Multinational Companies," Survey of Current Business, 75:38-53.

Meyer, John R. and Edwin Kuh (1957), The Investment Decision: An Empirical Study, Cambridge MA: Harvard University Press.

Miller, Merton H. (1977), “Debt and Taxes,” Journal of Finance, 32:261-275.

Myers, Stewart, John McConnell, Alice Peterson, Dennis Soter and Joel Stern (1998), "Vanderbilt University Roundtable On The Capital Structure Puzzle, " Journal of Applied Corporate Finance, 11:8-24.

Noe, Thomas H. (2000), “Creditor Rights and Multinational Capital Structure," Tulane University Working Paper.

Novaes, Walter (2003), "Political Risk and Capital Structure Choice of Foreign Subsidiaries: An Empirical Analysis," University of Washington Working Paper.

Powers, Timothy E. (1993), “The Model International Insolvency Co-operation Act: A $21^{\text {st }}$ Century Proposal for International Insolvency Co-operation," in Multinational Commercial Insolvency, American Bar Association.

Rajan, Raghuram and Luigi Zingales (1995), "What do We Know About Capital Structure? Some Evidence from International Data," Journal of Finance, 50:14211460 . 
Rajan, Raghuram G. and Luigi Zingales (1998), "Financial Dependence and Growth," American Economic Review, 88:559-586.

Rajan, Raghuram, and Luigi Zingales (forthcoming), "Great Reversals: The Politics of Financial Development in the 20th Century," Journal of Financial Economics.

Scharfstein, David and Jeremy C. Stein (2000), "The Dark Side of Internal Capital Markets: Divisional Rent-Seeking and Inefficient Investment," Journal of Finance, $55: 2537-2564$.

Shin, Hyun-Han and Rene Stulz (1998), "Are Internal Capital Markets Efficient?," Quarterly Journal of Economics, 113:531-552.

Shleifer, Andrei and Daniel Wolfenzon (2002), "Investor Protection and Equity Markets," Journal of Financial Economics, 66:3-27.

Stein, Jeremy C. (1997), "Internal Capital Markets and the Competition for Corporate Resources," Journal of Finance, 52:111-133.

Tagashira, Shoichi (1994), "International Effects of Foreign Insolvency Proceedings: An Analysis of "Ancillary' Proceedings in the United States and Japan," Texas International Law Journal, 29:1-38.

Titman, Sheridan and Roberto Wessels (1998), "The Determinants of Capital Structure Choice," Journal of Finance, 43:1-19.

United States Department of Commerce (1998), U.S. Direct Investment Abroad: 1994 Benchmark Survey, Final Results (Washington, DC: U.S. Department of Commerce). 
Figure 1: The Relationship Between Tax Rates and Affiliate Leverage, 1994

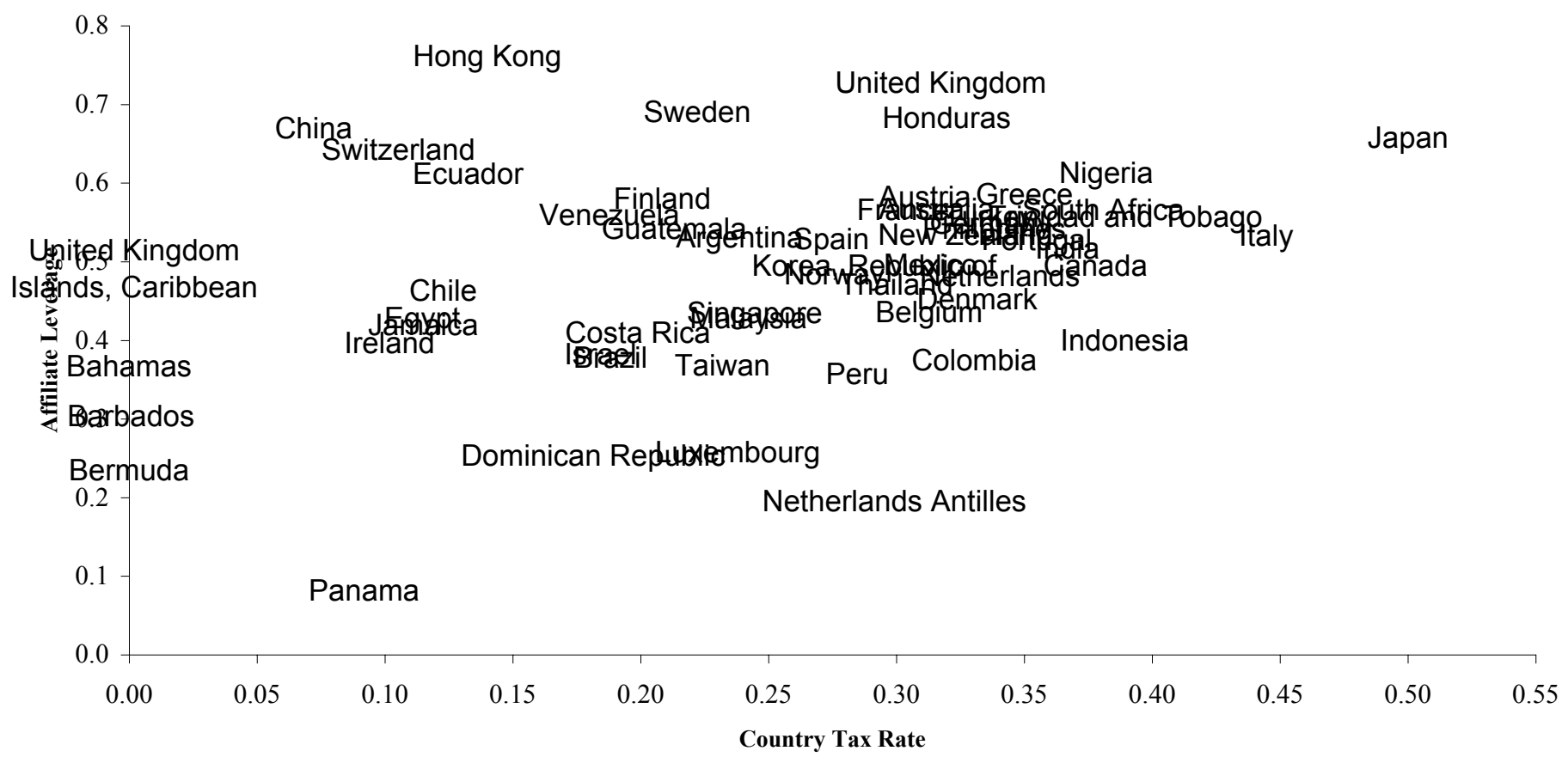

Note: The figure provides a scatterplot of the relationship between affiliate leverage, on the y-axis, and local tax rates, on the x-axis, for 1994 . Affiliate leverage is the ratio of current liabilities and long-term debt to total assets as measured in the aggregate in the 1994 Benchmark Survey and the tax rate is measured as the median tax rate, as defined in the text, for affiliates in a given country.

\section{Figure 2: The Relationship Between Capital Market Depth and Affiliate Leverage, 1994}

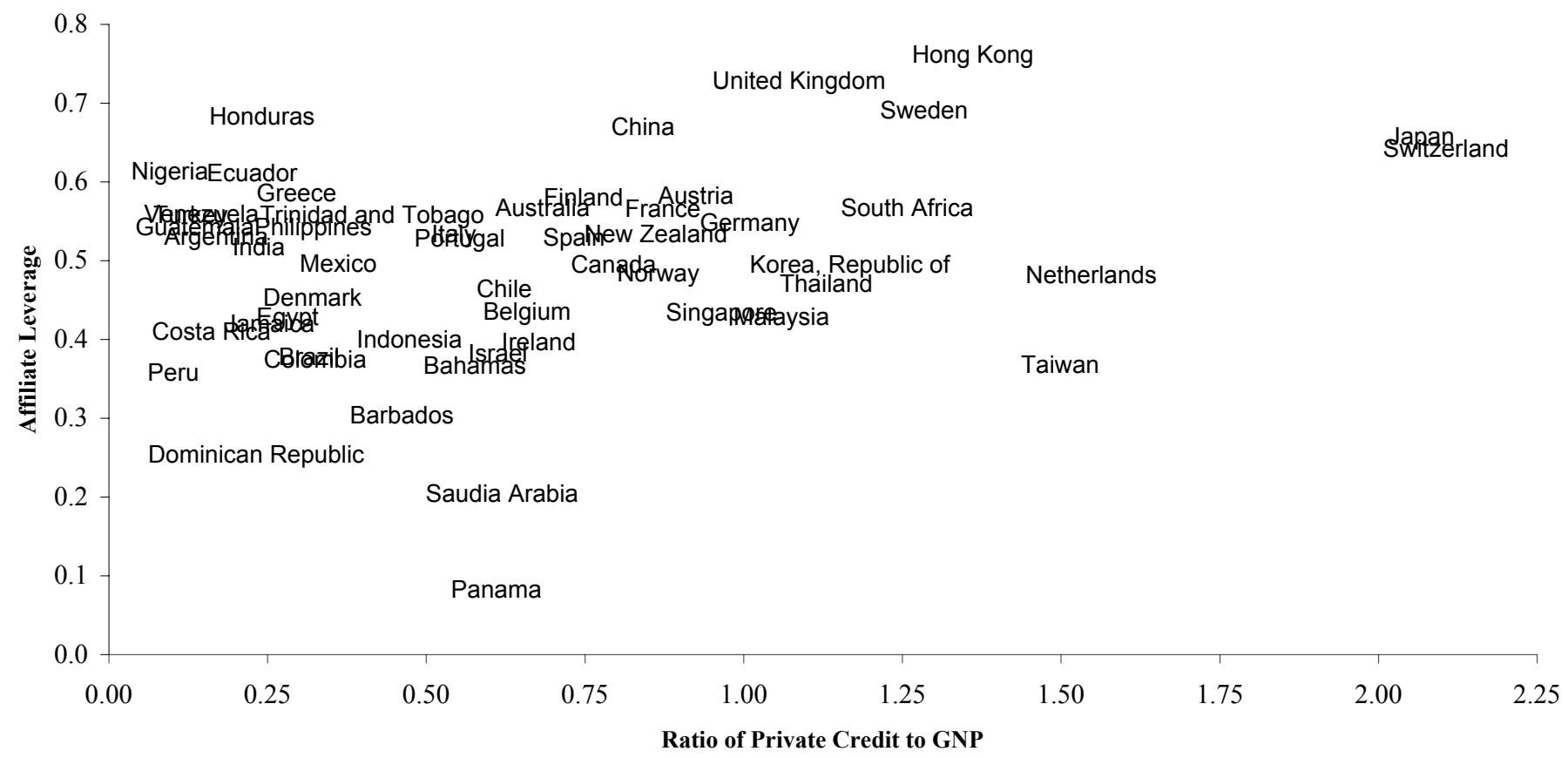

Note: The figure provides a scatterplot of the relationship between affiliate leverage, on the y-axis, and the ratio of private credit to GNP, on the xaxis, for 1994. Affiliate leverage is the ratio of current liabilities and long-term debt to total assets as measured in the aggregate in the 1994 Benchmark Survey and the ratio of private credit to GNP is the ratio of private credit lent by deposit money banks to GDP, as provided in Beck, Demirguc-Kunt, and Levine (1999). 


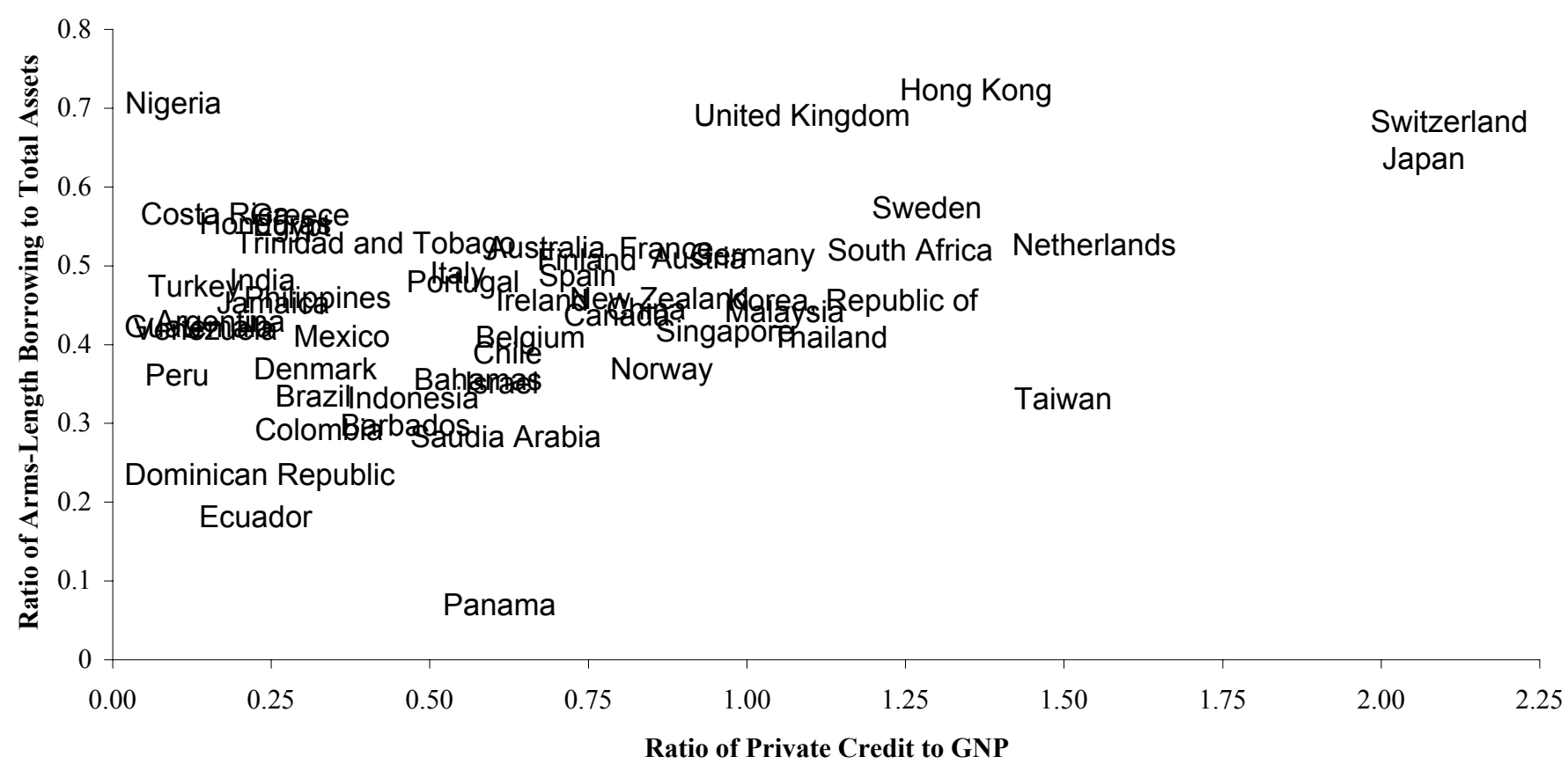

Note: The figure provides a scatterplot of the relationship between arms-length borrowing, on the y-axis, and the ratio of private credit to GNP, on the $\mathrm{x}$-axis, for 1994. Arms-length borrowing is the ratio of borrowings from unrelated parties to total assets as measured in the aggregate in the 1994 Benchmark Survey and the ratio of private credit to GNP is the ratio of private credit lent by deposit money banks to GDP, as provided in Beck, Demirguc-Kunt, and Levine (1999).

\section{Figure 4: The Relationship Between Creditor Rights and Affiliate Leverage, 1994}

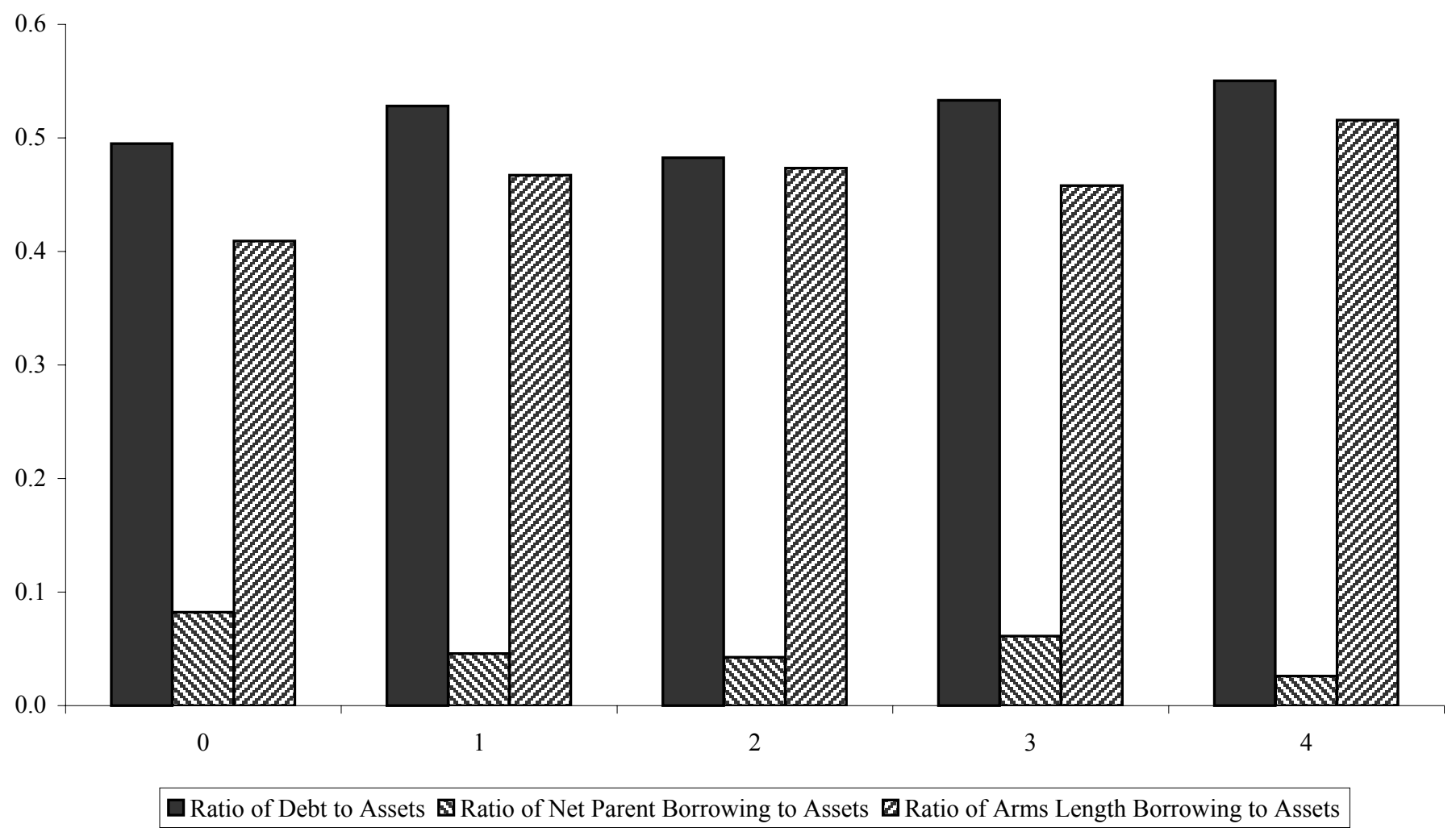

Note: The figure provides the median ratio of debt to assets, debt from the parent to assets, and unrelated party debt to assets by rating for creditor rights in 1994. 
Table I

Descriptive Statistics for Affiliates of U.S. Multinationals in 1982, 1989, 1994

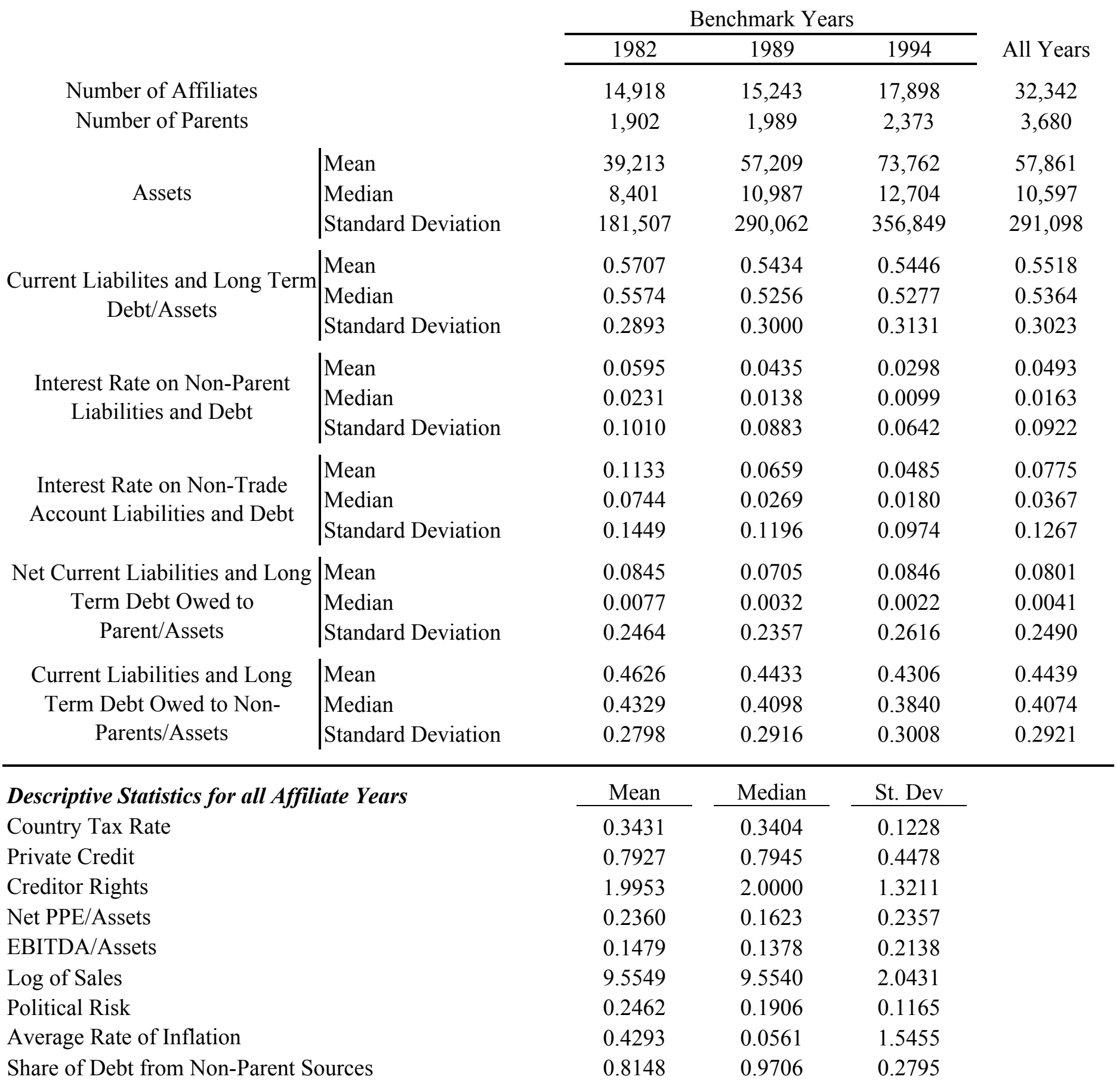

\footnotetext{
Notes: The top panel provides descriptive statistics for dependent variables for all affiliates of U.S. multinationals by year and for the entire sample. Current Liabilites and Long Term Debt/Assets is the ratio of affiliate current liabilities and long term debt to total affiliate assets. The Interest Rate on Non-Parent Liabilities and Debt is the interest rate an individual affiliate pays for external debt, measured as the ratio of the value of affiliate interest payments to non-parents to current liabilities and long term debt borrowed from non-parent sources. Interest Rate on Non-Trade Account Liabilities and Debt is the ratio of total affiliate interest payments to current liabilities and long term debt, excluding trade accounts. Net Current Liabilities and Long Term Debt Owed to Parent/Assets is the ratio of the difference between current liabilities and long term debt an affiliate borrows from and lends to its U.S. parent to total affiliate assets. Current Liabilities and Long Term Debt Owed to Non-Parents/Assets is the ratio of current liabilities and long term debt an affiliate borrows from non-parent sources to total affiliate assets. The bottom panel reports descriptive statistics for control variables for all affiliates across all years. Country Tax Rate is the median tax rate in an affiliate's host country measured on an annual basis in the manner described in the text. Private Credit is the ratio of private credit lent by deposit money banks to GDP, as provided in Beck, Demirguc-Kunt, and Levine (1999). Creditor Rights is an index of the strength of creditor rights developed in LaPorta, Lopez-de-Silanes, Shleifer, and Vishny (1998); higher levels of the measure which ranges from 0 to 4 indicate stronger legal protections. Net PPE/Assets is the ratio of affiliate net property, plant and equipment to total affiliate assets. EBITDA/Assets is the ratio of affiliate earnings before interest, taxes, depreciation and amortization to total affiliate assets. Log of Sales is the natural log of affiliate sales. Political Risk is an index of the average level of political risk over the 1982-1994 period derived from the International Country Risk Guide, rescaled to lie between 0 and 1 with higher numbers indicating higher risks. Average Rate of Inflation is the average percentage change in the GDP deflator of an affiliate's host country over the 1982-1994 period. Share of Debt from Non-Parent Sources is the share of affiliate current liabilities and long term debt owed to lenders other than the affiliate's parent.
} 
Table II

The Impact of Taxes and Capital Market Conditions on Multinational Affiliate Leverage

Dependent Variable: Current Liabilities and Long Term Debt/Assets

\begin{tabular}{|c|c|c|c|c|c|c|c|c|c|c|}
\hline \multicolumn{11}{|c|}{ Dependent Variable: Current Liabilities and Long Term Debt/Assets } \\
\hline & $(1)$ & (2) & (3) & (4) & $(5)$ & (6) & $(7)$ & $(8)$ & $(9)$ & $(10)$ \\
\hline Constant & $\begin{array}{c}0.4657 \\
(0.0073)\end{array}$ & $\begin{array}{c}0.6827 \\
(0.0665)\end{array}$ & $\begin{array}{c}0.4545 \\
(0.0094)\end{array}$ & $\begin{array}{c}0.6878 \\
(0.0799)\end{array}$ & $\begin{array}{c}0.4129 \\
(0.0110)\end{array}$ & $\begin{array}{c}0.5782 \\
(0.0496)\end{array}$ & $\begin{array}{c}0.4859 \\
(0.0278)\end{array}$ & $\begin{array}{c}0.2942 \\
(0.1020)\end{array}$ & $\begin{array}{c}0.4684 \\
(0.0265)\end{array}$ & $\begin{array}{c}0.1690 \\
(0.1125)\end{array}$ \\
\hline Country Tax Rate & $\begin{array}{c}0.2508 \\
(0.0230)\end{array}$ & $\begin{array}{c}0.2646 \\
(0.0205)\end{array}$ & $\begin{array}{c}0.2469 \\
(0.0250)\end{array}$ & $\begin{array}{c}0.2608 \\
(0.0235)\end{array}$ & $\begin{array}{c}0.3082 \\
(0.0273)\end{array}$ & $\begin{array}{c}0.3206 \\
(0.0226)\end{array}$ & $\begin{array}{c}0.2499 \\
(0.0314)\end{array}$ & $\begin{array}{c}0.2560 \\
(0.0315)\end{array}$ & $\begin{array}{c}0.2713 \\
(0.0309)\end{array}$ & $\begin{array}{c}0.2789 \\
(0.0299)\end{array}$ \\
\hline Private Credit & & & $\begin{array}{c}0.0166 \\
(0.0061)\end{array}$ & $\begin{array}{l}-0.0051 \\
(0.0052)\end{array}$ & & & $\begin{array}{c}0.0140 \\
(0.0091)\end{array}$ & $\begin{array}{c}0.0060 \\
(0.0078)\end{array}$ & & \\
\hline Creditor Rights & & & & & $\begin{array}{c}0.0153 \\
(0.0030)\end{array}$ & $\begin{array}{c}0.0082 \\
(0.0020)\end{array}$ & & & $\begin{array}{c}0.0114 \\
(0.0031)\end{array}$ & $\begin{array}{c}0.0060 \\
(0.0024)\end{array}$ \\
\hline Net PPE/Assets & & & & & & & $\begin{array}{l}-0.1430 \\
(0.0147)\end{array}$ & $\begin{array}{c}-0.0199 \\
(0.0160)\end{array}$ & $\begin{array}{c}-0.1554 \\
(0.0146)\end{array}$ & $\begin{array}{c}-0.0239 \\
(0.0166)\end{array}$ \\
\hline EBITDA/Assets & & & & & & & $\begin{array}{l}-0.4443 \\
(0.0149)\end{array}$ & $\begin{array}{c}-0.4192 \\
(0.0162)\end{array}$ & $\begin{array}{c}-0.4494 \\
(0.0152)\end{array}$ & $\begin{array}{c}-0.4266 \\
(0.0166)\end{array}$ \\
\hline Log of Sales & & & & & & & $\begin{array}{c}0.0027 \\
(0.0018)\end{array}$ & $\begin{array}{c}0.0005 \\
(0.0022)\end{array}$ & $\begin{array}{c}0.0036 \\
(0.0018)\end{array}$ & $\begin{array}{c}0.0018 \\
(0.0022)\end{array}$ \\
\hline Political Risk & & & & & & & $\begin{array}{c}0.1719 \\
(0.0364)\end{array}$ & $\begin{array}{c}0.1703 \\
(0.0338)\end{array}$ & $\begin{array}{c}0.1257 \\
(0.0338)\end{array}$ & $\begin{array}{c}0.1737 \\
(0.0326)\end{array}$ \\
\hline Average Rate of Inflation & & & & & & & $\begin{array}{l}-0.0040 \\
(0.0017)\end{array}$ & $\begin{array}{c}-0.0021 \\
(0.0015)\end{array}$ & $\begin{array}{c}-0.0016 \\
(0.0018)\end{array}$ & $\begin{array}{c}-0.0012 \\
(0.0015)\end{array}$ \\
\hline $\begin{array}{l}\text { Parent, Industry, and Year } \\
\text { Fixed Effects? }\end{array}$ & $\mathrm{N}$ & Y & $\mathrm{N}$ & $\mathrm{Y}$ & $\mathrm{N}$ & $\mathrm{Y}$ & $\mathrm{N}$ & $\mathrm{Y}$ & $\mathrm{N}$ & $\mathrm{Y}$ \\
\hline No. of Obs. & 44,460 & 44,460 & 42,639 & 42,639 & 39,995 & 39,995 & 19,983 & 19,983 & 19,209 & 19,209 \\
\hline R-Squared & 0.0102 & 0.2286 & 0.0095 & 0.2329 & 0.0150 & 0.2460 & 0.1107 & 0.3339 & 0.1180 & 0.3453 \\
\hline
\end{tabular}

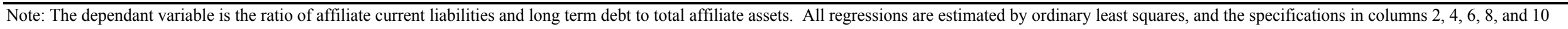

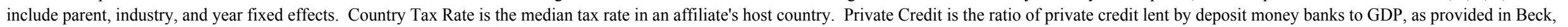

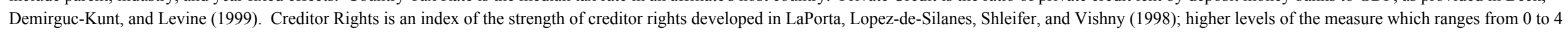

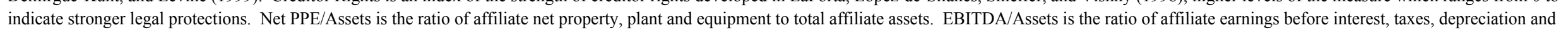

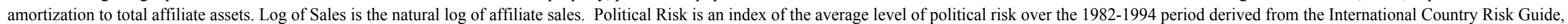

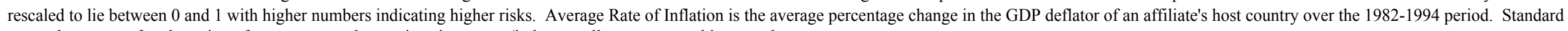
errors that correct for clustering of errors across observations in country/industry cells are presented in parentheses. 
Table III

Determinants of Local Interest Rates

Dependent Variable: Interest Rate on Non-Parent Liabilities and Debt

(1)

(2)

(3)

(4)

(5)

(6)

(7)

(8)

\begin{tabular}{|c|c|c|c|c|c|c|c|c|}
\hline Constant & $\begin{array}{c}0.0833 \\
(0.0034)\end{array}$ & $\begin{array}{l}-0.0387 \\
(0.0337)\end{array}$ & $\begin{array}{c}0.0707 \\
(0.0027)\end{array}$ & $\begin{array}{c}0.0254 \\
(0.0223)\end{array}$ & $\begin{array}{c}0.0514 \\
(0.0070)\end{array}$ & $\begin{array}{l}-0.0533 \\
(0.0222)\end{array}$ & $\begin{array}{c}0.0410 \\
(0.0066)\end{array}$ & $\begin{array}{l}-0.0097 \\
(0.0239)\end{array}$ \\
\hline Country Tax Rate & & & & & $\begin{array}{c}0.0179 \\
(0.0084)\end{array}$ & $\begin{array}{l}-0.0323 \\
(0.0105)\end{array}$ & $\begin{array}{c}0.0203 \\
(0.0084)\end{array}$ & $\begin{array}{l}-0.0321 \\
(0.0116)\end{array}$ \\
\hline Private Credit & $\begin{array}{l}-0.0443 \\
(0.0033)\end{array}$ & $\begin{array}{l}-0.0385 \\
(0.0034)\end{array}$ & & & $\begin{array}{l}-0.0185 \\
(0.0022)\end{array}$ & $\begin{array}{l}-0.0096 \\
(0.0023)\end{array}$ & & \\
\hline Creditor Rights & & & $\begin{array}{l}-0.0104 \\
(0.0008)\end{array}$ & $\begin{array}{l}-0.0093 \\
(0.0008)\end{array}$ & & & $\begin{array}{c}-0.0056 \\
(0.0006)\end{array}$ & $\begin{array}{l}-0.0052 \\
(0.0006)\end{array}$ \\
\hline Net PPE/Assets & & & & & $\begin{array}{c}0.0292 \\
(0.0034)\end{array}$ & $\begin{array}{c}0.0395 \\
(0.0046)\end{array}$ & $\begin{array}{c}0.0315 \\
(0.0036)\end{array}$ & $\begin{array}{c}0.0404 \\
(0.0048)\end{array}$ \\
\hline EBITDA/Assets & & & & & $\begin{array}{l}-0.0133 \\
(0.0053)\end{array}$ & $\begin{array}{l}-0.0079 \\
(0.0059)\end{array}$ & $\begin{array}{l}-0.0156 \\
(0.0054)\end{array}$ & $\begin{array}{l}-0.0095 \\
(0.0060)\end{array}$ \\
\hline Log of Sales & & & & & $\begin{array}{l}-0.0010 \\
(0.0004)\end{array}$ & $\begin{array}{c}0.0011 \\
(0.0005)\end{array}$ & $\begin{array}{l}-0.0019 \\
(0.0004)\end{array}$ & $\begin{array}{c}0.0010 \\
(0.0005)\end{array}$ \\
\hline Political Risk & & & & & $\begin{array}{c}0.0169 \\
(0.0094)\end{array}$ & $\begin{array}{c}0.0463 \\
(0.0095)\end{array}$ & $\begin{array}{c}0.0860 \\
(0.0113)\end{array}$ & $\begin{array}{c}0.0880 \\
(0.0104)\end{array}$ \\
\hline $\begin{array}{l}\text { Average Rate of } \\
\text { Inflation }\end{array}$ & & & & & $\begin{array}{c}0.0187 \\
(0.0010)\end{array}$ & $\begin{array}{c}0.0181 \\
(0.0009)\end{array}$ & $\begin{array}{c}0.0181 \\
(0.0010)\end{array}$ & $\begin{array}{c}0.0176 \\
(0.0010)\end{array}$ \\
\hline $\begin{array}{l}\text { Parent, Industry, and } \\
\text { Year Fixed Effects? }\end{array}$ & $\mathrm{N}$ & Y & $\mathrm{N}$ & Y & $\mathrm{N}$ & Y & $\mathrm{N}$ & $\mathrm{Y}$ \\
\hline No. of Obs. & 20,587 & 20,587 & 19,687 & 19,687 & 19,904 & 19,904 & 19,134 & 19,134 \\
\hline R-Squared & 0.0377 & 0.1791 & 0.0221 & 0.1758 & 0.1455 & 0.2797 & 0.1596 & 0.2931 \\
\hline
\end{tabular}

\footnotetext{
Note: The dependant variable is the interest rate an individual affiliate pays for external debt, measured as the ratio of the value of affiliate interest payments to non-parents to current liabilities and long term debt borrowed from non-parent sources. All regressions are estimated by ordinary least squares, and the specifications in columns 2, 4, 6, and 8 include parent, industry, and year fixed effects. Country Tax Rate is the median tax rate in an affiliate's host country. Private Credit is the ratio of private credit lent by deposit money banks to GDP, as provided in Beck, Demirguc-Kunt, and Levine (1999). Creditor Rights is an index of the strength of creditor rights developed in LaPorta, Lopez-de-Silanes, Shleifer, and Vishny (1998); higher levels of the measure which ranges from 0 to 4 indicate stronger legal protections. Net PPE/Assets is the ratio of affiliate net property, plant and equipment to total affiliate assets. EBITDA/Assets is the ratio of affiliate earnings before interest, taxes, depreciation and amortization to total affiliate assets. Log of Sales is the natural log of affiliate sales. Political Risk is an index of the average level of political risk over the 1982-1994 period derived from the International Country Risk Guide, rescaled to lie between 0 and 1 with higher numbers indicating higher risks. Average Rate of Inflation is the average percentage change in the GDP deflator of an affiliate's host country over the 1982-1994 period. Standard errors that correct for clustering of errors across observations in country/industry cells are presented in parentheses.
} 
Table IV

Determinants of Interest Rates

Dependent Variable: Interest Rate Paid on Non-Trade Account Liabilities and Debt

\begin{tabular}{|c|c|c|c|c|c|c|c|c|}
\hline & (1) & (2) & (3) & (4) & (5) & (6) & (7) & (8) \\
\hline Constant & $\begin{array}{c}0.0810 \\
(0.0105)\end{array}$ & $\begin{array}{c}0.1203 \\
(0.0557)\end{array}$ & $\begin{array}{c}0.0549 \\
(0.0107)\end{array}$ & $\begin{array}{c}0.0861 \\
(0.0564)\end{array}$ & $\begin{array}{c}0.0505 \\
(0.0128)\end{array}$ & $\begin{array}{l}-0.0338 \\
(0.0472)\end{array}$ & $\begin{array}{c}0.0221 \\
(0.0122)\end{array}$ & $\begin{array}{c}0.0538 \\
(0.0580)\end{array}$ \\
\hline Country Tax Rate & $\begin{array}{c}0.0745 \\
(0.0139)\end{array}$ & $\begin{array}{l}-0.0330 \\
(0.0152)\end{array}$ & $\begin{array}{c}0.0828 \\
(0.0141)\end{array}$ & $\begin{array}{l}-0.0328 \\
(0.0164)\end{array}$ & $\begin{array}{c}0.0735 \\
(0.0138)\end{array}$ & $\begin{array}{l}-0.0342 \\
(0.0151)\end{array}$ & $\begin{array}{c}0.0841 \\
(0.0140)\end{array}$ & $\begin{array}{l}-0.0319 \\
(0.0164)\end{array}$ \\
\hline Private Credit & $\begin{array}{l}-0.0322 \\
(0.0036)\end{array}$ & $\begin{array}{l}-0.0093 \\
(0.0033)\end{array}$ & & & $\begin{array}{l}-0.0157 \\
(0.0087)\end{array}$ & $\begin{array}{c}0.0091 \\
(0.0088)\end{array}$ & & \\
\hline Creditor Rights & & & $\begin{array}{l}-0.0072 \\
(0.0010)\end{array}$ & $\begin{array}{l}-0.0049 \\
(0.0008)\end{array}$ & & & $\begin{array}{c}0.0008 \\
(0.0026)\end{array}$ & $\begin{array}{c}0.0014 \\
(0.0026)\end{array}$ \\
\hline $\begin{array}{l}\text { Share of Debt from Non-Parent } \\
\text { Sources }\end{array}$ & & & & & $\begin{array}{c}0.0440 \\
(0.0103)\end{array}$ & $\begin{array}{c}0.0278 \\
(0.0100)\end{array}$ & $\begin{array}{c}0.0443 \\
(0.0084)\end{array}$ & $\begin{array}{c}0.0232 \\
(0.0081)\end{array}$ \\
\hline $\begin{array}{l}\text { Share of Debt from Non-Parent } \\
\text { Sources * Private Credit }\end{array}$ & & & & & $\begin{array}{l}-0.0204 \\
(0.0101)\end{array}$ & $\begin{array}{l}-0.0222 \\
(0.0099)\end{array}$ & & \\
\hline $\begin{array}{l}\text { Share of Debt from Non-Parent } \\
\text { Sources * Creditor Rights }\end{array}$ & & & & & & & $\begin{array}{l}-0.0097 \\
(0.0030)\end{array}$ & $\begin{array}{l}-0.0078 \\
(0.0030)\end{array}$ \\
\hline Net PPE/Assets & $\begin{array}{c}0.0215 \\
(0.0052)\end{array}$ & $\begin{array}{c}0.0378 \\
(0.0067)\end{array}$ & $\begin{array}{c}0.0262 \\
(0.0054)\end{array}$ & $\begin{array}{c}0.0369 \\
(0.0069)\end{array}$ & $\begin{array}{c}0.0236 \\
(0.0051)\end{array}$ & $\begin{array}{c}0.0390 \\
(0.0068)\end{array}$ & $\begin{array}{c}0.0282 \\
(0.0052)\end{array}$ & $\begin{array}{c}0.0381 \\
(0.0070)\end{array}$ \\
\hline EBITDA/Assets & $\begin{array}{c}0.0053 \\
(0.0075)\end{array}$ & $\begin{array}{c}0.0165 \\
(0.0080)\end{array}$ & $\begin{array}{l}-0.0006 \\
(0.0076)\end{array}$ & $\begin{array}{c}0.0121 \\
(0.0081)\end{array}$ & $\begin{array}{c}0.0011 \\
(0.0075)\end{array}$ & $\begin{array}{c}0.0155 \\
(0.0081)\end{array}$ & $\begin{array}{l}-0.0044 \\
(0.0076)\end{array}$ & $\begin{array}{c}0.0115 \\
(0.0082)\end{array}$ \\
\hline Log of Sales & $\begin{array}{l}-0.0017 \\
(0.0006)\end{array}$ & $\begin{array}{c}0.0015 \\
(0.0008)\end{array}$ & $\begin{array}{l}-0.0028 \\
(0.0007)\end{array}$ & $\begin{array}{c}0.0016 \\
(0.0008)\end{array}$ & $\begin{array}{l}-0.0023 \\
(0.0006)\end{array}$ & $\begin{array}{c}0.0015 \\
(0.0008)\end{array}$ & $\begin{array}{l}-0.0033 \\
(0.0007)\end{array}$ & $\begin{array}{c}0.0015 \\
(0.0008)\end{array}$ \\
\hline Political Risk & $\begin{array}{c}0.0003 \\
(0.0169)\end{array}$ & $\begin{array}{c}0.0749 \\
(0.0154)\end{array}$ & $\begin{array}{c}0.1024 \\
(0.0204)\end{array}$ & $\begin{array}{c}0.1199 \\
(0.0172)\end{array}$ & $\begin{array}{c}0.0060 \\
(0.0162)\end{array}$ & $\begin{array}{c}0.0785 \\
(0.0153)\end{array}$ & $\begin{array}{c}0.1083 \\
(0.0196)\end{array}$ & $\begin{array}{c}0.1241 \\
(0.0171)\end{array}$ \\
\hline Average Rate of Inflation & $\begin{array}{c}0.0207 \\
(0.0015)\end{array}$ & $\begin{array}{c}0.0192 \\
(0.0013)\end{array}$ & $\begin{array}{c}0.0207 \\
(0.0015)\end{array}$ & $\begin{array}{c}0.0189 \\
(0.0013)\end{array}$ & $\begin{array}{c}0.0205 \\
(0.0015)\end{array}$ & $\begin{array}{c}0.0191 \\
(0.0013)\end{array}$ & $\begin{array}{c}0.0205 \\
(0.0015)\end{array}$ & $\begin{array}{c}0.0189 \\
(0.0013)\end{array}$ \\
\hline $\begin{array}{l}\text { Parent, Industry, and Year } \\
\text { Fixed Effects? }\end{array}$ & $\mathrm{N}$ & Y & $\mathrm{N}$ & Y & $\mathrm{N}$ & Y & $\mathrm{N}$ & Y \\
\hline No. of Obs. & 14,322 & 14,322 & 13,814 & 13,814 & 14,242 & 14,242 & 13,743 & 13,743 \\
\hline R-Squared & 0.1041 & 0.3223 & 0.1133 & 0.3332 & 0.1081 & 0.3241 & 0.1171 & 0.3349 \\
\hline
\end{tabular}

Note: The dependant variable is the interest rate an individual affiliate pays, measured as the ratio of total affiliate interest payments to current liabilities and long term debt, excluding trade accounts. All regressions are estimated by ordinary least squares, and the specifications in columns 2, 4, 6, and 8 include parent, industry, and year fixed effects. Country Tax Rate is the median tax rate in an affiliate's host country. Private Credit is the ratio of private credit lent by deposit money banks to GDP, as provided in Beck, Demirguc-Kunt, and Levine (1999). Creditor Rights is an index of the strength of creditor rights developed in LaPorta, Lopez-de-Silanes, Shleifer, and Vishny (1998); higher levels of the measure which ranges from 0 to 4 indicate stronger legal protections. Share of Debt from Non-Parent Sources is the share of affiliate current liabilities and long term debt owed to lenders other than the affiliate's parent. Net PPE/Assets is the ratio of affiliate net property, plant and equipment to total affiliate assets. EBITDA/Assets is the ratio of affiliate earnings before interest, taxes, depreciation and amortization to total affiliate assets. Log of Sales is the natural log of affiliate sales. Political Risk is an index of the average level of political risk over the 1982-1994 period derived from the International Country Risk Guide, rescaled to lie between 0 and 1 with higher numbers indicating higher risks. Average Rate of Inflation is the average percentage change in the GDP deflator of an affiliate's host country over the 1982-1994 period. Standard errors that correct for clustering of errors across observations in country/industry cells are presented in parentheses. 
Table V

Determinants of Net Borrowing From the Parent

Dependent Variable: Net Current Liabilities and Long Term Debt Owed to Parent/Assets

\section{(1)}

(2)

(3)

(4)

(5)

(6)

(7)

(8)

0.1000

0.1124

$-0.0649$

0.0572

(0.1691)

(0.0071)

(0.0387)

(0.0079)

(0.0806)

(0.0231)

$-0.1324$

(0.1082)

0.1141

(0.0207)

0.1230

$(0.0235)$

0.0800

(0.0236)

0.1262

(0.0250)

$-0.0091$

$-0.0147$

$-0.0201$

$-0.0314$

(0.0045)

(0.0038)

Creditor Rights

Net PPE/Assets

EBITDA/Assets

Log of Sales

Political Risk

Average Rate of Inflation

Parent, Industry, and Year

Fixed Effects?

No. of Obs.

R-Squared

$\begin{array}{ll}-0.0024 & -0.0042 \\ (0.0020) & (0.0013)\end{array}$

(0.0082)

(0.0065)

(0.0020)

(0.0013)

0.0578
$(0.0110)$

\subsection{3}

(0.0143)

$-0.2189$

$-0.2145$

(0.0118)

(0.0127)

$-0.0068$

(0.0014)

$-0.0018$

(0.0018)

0.0774

0.1108

(0.0272)

(0.0252)

$-0.0002$

0.0004

(0.0010)

(0.0010)

$-0.0020$

(0.0022)
$-0.0037$

(0.0016)

$0.0481 \quad 0.0918$

$(0.0113) \quad(0.0146)$

$-0.2097-0.2055$

$(0.0121) \quad(0.0126)$

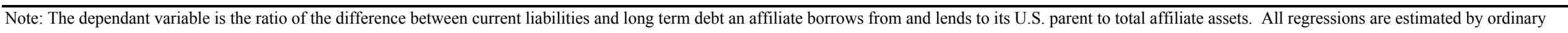

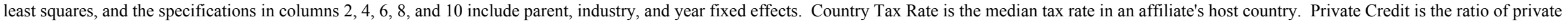

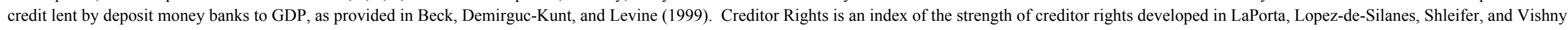

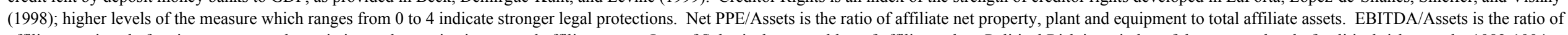

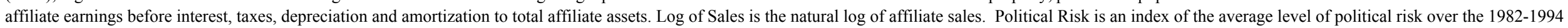

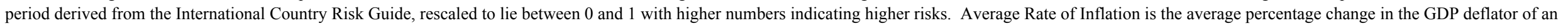
affiliate's host country over the 1982-1994 period. Standard errors that correct for clustering of errors across observations in country/industry cells are presented in parentheses. 
Table VI

Capital Availability and External Borrowing

Dependent Variable: Current Liabilities and Long Term Debt Owed to Non-Parents/Assets

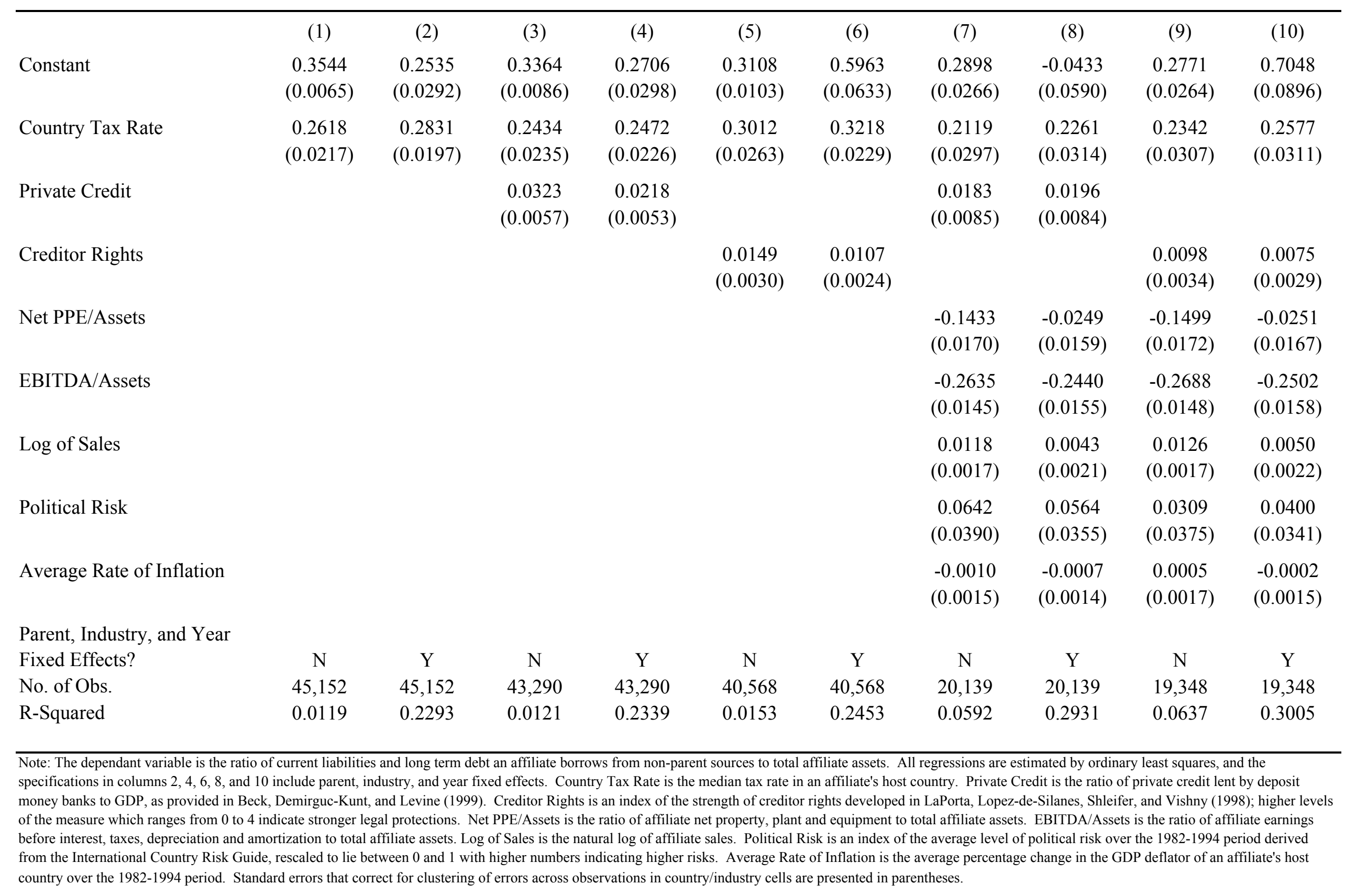


Table VII

The Responsiveness of External and Parent Debt to External Interest Rates

\begin{tabular}{|c|c|c|c|c|c|c|c|c|}
\hline \multirow[t]{2}{*}{ Dependent Variable: } & \multicolumn{4}{|c|}{$\begin{array}{c}\text { Current Liabilities and Long Term Debt } \\
\text { Owed to Non-Parents/Assets }\end{array}$} & \multicolumn{4}{|c|}{$\begin{array}{l}\text { Net Current Liabilities and Long Term Debt } \\
\text { Owed to Parents/Assets }\end{array}$} \\
\hline & (1) & (2) & (3) & (4) & $(5)$ & (6) & (7) & (8) \\
\hline Constant & $\begin{array}{c}0.4487 \\
(0.0050)\end{array}$ & $\begin{array}{c}0.1139 \\
(0.0934)\end{array}$ & $\begin{array}{c}0.3183 \\
(0.4432)\end{array}$ & $\begin{array}{c}0.0224 \\
(0.3072)\end{array}$ & $\begin{array}{c}0.0640 \\
(0.0030)\end{array}$ & $\begin{array}{c}0.1970 \\
(0.0532)\end{array}$ & $\begin{array}{l}-0.0481 \\
(0.3249)\end{array}$ & $\begin{array}{c}0.0641 \\
(0.2191)\end{array}$ \\
\hline $\begin{array}{l}\text { Interest Rate on Non-Parent } \\
\text { Liabilities and Debt }\end{array}$ & $\begin{array}{l}-0.0394 \\
(0.0251)\end{array}$ & $\begin{array}{c}0.0010 \\
(0.0280)\end{array}$ & $\begin{array}{l}-2.0077 \\
(0.7485)\end{array}$ & $\begin{array}{l}-1.4749 \\
(0.3167)\end{array}$ & $\begin{array}{c}0.2434 \\
(0.0258)\end{array}$ & $\begin{array}{c}0.2697 \\
(0.0259)\end{array}$ & $\begin{array}{c}1.4386 \\
(0.5496)\end{array}$ & $\begin{array}{c}0.6488 \\
(0.2259)\end{array}$ \\
\hline Country Tax Rate & & $\begin{array}{c}0.2326 \\
(0.0289)\end{array}$ & $\begin{array}{c}0.1600 \\
(0.0342)\end{array}$ & $\begin{array}{c}0.2128 \\
(0.0245)\end{array}$ & & $\begin{array}{c}0.0888 \\
(0.0230)\end{array}$ & $\begin{array}{c}0.1335 \\
(0.0250)\end{array}$ & $\begin{array}{c}0.0973 \\
(0.0175)\end{array}$ \\
\hline Net PPE/Assets & & $\begin{array}{l}-0.0267 \\
(0.0159)\end{array}$ & $\begin{array}{c}0.0528 \\
(0.0338)\end{array}$ & $\begin{array}{c}0.0355 \\
(0.0188)\end{array}$ & & $\begin{array}{c}0.0881 \\
(0.0146)\end{array}$ & $\begin{array}{c}0.0312 \\
(0.0247)\end{array}$ & $\begin{array}{c}0.0552 \\
(0.0133)\end{array}$ \\
\hline EBITDA/Assets & & $\begin{array}{l}-0.2464 \\
(0.0152)\end{array}$ & $\begin{array}{l}-0.2632 \\
(0.0140)\end{array}$ & $\begin{array}{l}-0.2666 \\
(0.0122)\end{array}$ & & $\begin{array}{l}-0.2071 \\
(0.0118)\end{array}$ & $\begin{array}{l}-0.1971 \\
(0.0099)\end{array}$ & $\begin{array}{c}-0.1987 \\
(0.0086)\end{array}$ \\
\hline Log of Sales & & $\begin{array}{c}0.0019 \\
(0.0021)\end{array}$ & $\begin{array}{c}0.0033 \\
(0.0019)\end{array}$ & $\begin{array}{c}0.0032 \\
(0.0017)\end{array}$ & & $\begin{array}{l}-0.0019 \\
(0.0018)\end{array}$ & $\begin{array}{l}-0.0039 \\
(0.0014)\end{array}$ & $\begin{array}{l}-0.0032 \\
(0.0012)\end{array}$ \\
\hline Political Risk & & $\begin{array}{l}-0.0023 \\
(0.0309)\end{array}$ & $\begin{array}{c}0.1441 \\
(0.0549)\end{array}$ & $\begin{array}{c}0.1649 \\
(0.0373)\end{array}$ & & $\begin{array}{c}0.1114 \\
(0.0235)\end{array}$ & $\begin{array}{c}0.0426 \\
(0.0405)\end{array}$ & $\begin{array}{c}0.0658 \\
(0.0266)\end{array}$ \\
\hline Average Rate of Inflation & & $\begin{array}{l}-0.0005 \\
(0.0015)\end{array}$ & $\begin{array}{c}0.0361 \\
(0.0138)\end{array}$ & $\begin{array}{c}0.0263 \\
(0.0060)\end{array}$ & & $\begin{array}{l}-0.0046 \\
(0.0010)\end{array}$ & $\begin{array}{l}-0.0263 \\
(0.0102)\end{array}$ & $\begin{array}{c}-0.0115 \\
(0.0043)\end{array}$ \\
\hline $\begin{array}{l}\text { Parent, Industry, and Year } \\
\text { Fixed Effects? }\end{array}$ & $\mathrm{N}$ & Y & Y & Y & $\mathrm{N}$ & Y & Y & Y \\
\hline IV using Private Credit? & $\mathrm{N}$ & $\mathrm{N}$ & Y & $\mathrm{N}$ & $\mathrm{N}$ & $\mathrm{N}$ & Y & $\mathrm{N}$ \\
\hline IV using Creditor Rights? & $\mathrm{N}$ & $\mathrm{N}$ & $\mathrm{N}$ & $\mathrm{Y}$ & $\mathrm{N}$ & $\mathrm{N}$ & $\mathrm{N}$ & $\mathrm{Y}$ \\
\hline $\begin{array}{l}\text { No. of Obs. } \\
\text { R-Squared }\end{array}$ & $\begin{array}{l}21,393 \\
0.0002\end{array}$ & $\begin{array}{l}20,331 \\
0.2896\end{array}$ & 19,784 & 19,017 & $\begin{array}{l}21,482 \\
0.0100\end{array}$ & $\begin{array}{l}20,407 \\
0.2905\end{array}$ & 19,858 & 19,092 \\
\hline
\end{tabular}

\footnotetext{
Note: The dependant variable in columns 1 through 4 is the ratio of current liabilities and long term debt an affiliate borrows from non-parent sources to total affiliate assets. The dependent variable in columns 5 through 8 is the ratio of the difference between current liabilities and long term debt an affiliate borrows from and lends to its U.S. parent to total affiliate assets. The Interest Rate on Non-Parent Liabilities and Debt is the interest rate an individual affiliate pays for external debt, measured as the ratio of the value of affiliate interest payments to non-parents to current liabilities and long term debt borrowed from non-parent sources. Country Tax Rate is the median tax rate in an affiliate's host country. Net PPE/Assets is the ratio of affiliate net property, plant and equipment to total affiliate assets. EBITDA/Assets is the ratio of affiliate earnings before interest, taxes, depreciation and amortization to total affiliate assets. Log of Sales is the natural log of affiliate sales. Political Risk is an index of the average level of political risk over the 1982-1994 period derived from the International Country Risk Guide, rescaled to lie between 0 and 1 with higher numbers indicating higher risks. Average Rate of Inflation is the average percentage change in the GDP deflator of an affiliate's host country over the 1982-1994 period. The specifications in columns 1, 2, 5, and 6 are estimated by ordinary least squares. The specifications in column 3 and 7 instrument for the Interest Rate on Non-Parent Debt using Private Credit. Private Credit is the ratio of private credit lent by deposit money banks to GDP, as provided in Beck, Demirguc-Kunt, and Levine (1999). The specifications in column 4 and 8 instrument for the Interest Rate on Non-Parent Debt using Creditor Rights. Creditor Rights is an index of the strength of creditor rights developed in LaPorta, Lopez-deSilanes, Shleifer, and Vishny (1998); higher levels of the measure which ranges from 0 to 4 indicate stronger legal protections. Specifications in columns 2, 3, 4, 6, 7, and 8 include parent, industry, and year fixed effects. Standard errors are presented in parentheses, and in columns 1, 2, 5, and 6 these errors correct for clustering of errors across observations in country/industry cells.
} 
Table VIII

The Substitutability of Parent and External Debt

Dependent Variable: Net Current Liabilities and Long Term Debt Owed to Parent/Assets

\begin{tabular}{|c|c|c|c|c|c|c|c|c|}
\hline & (1) & $(2)$ & (3) & (4) & (5) & (6) & (7) & $(8)$ \\
\hline Constant & $\begin{array}{c}0.1404 \\
(0.0050)\end{array}$ & $\begin{array}{c}0.0824 \\
(0.0178)\end{array}$ & $\begin{array}{c}0.1988 \\
(0.2272)\end{array}$ & $\begin{array}{c}0.0193 \\
(0.1679)\end{array}$ & $\begin{array}{c}0.1559 \\
(0.0225)\end{array}$ & $\begin{array}{c}0.0279 \\
(0.0632)\end{array}$ & $\begin{array}{c}0.1739 \\
(0.3802)\end{array}$ & $\begin{array}{c}0.0934 \\
(0.2341)\end{array}$ \\
\hline $\begin{array}{l}\text { Current Liabilities and Long } \\
\text { Term Debt Owed to Non- } \\
\text { Parents/Assets }\end{array}$ & $\begin{array}{l}-0.1346 \\
(0.0066)\end{array}$ & $\begin{array}{c}-0.1177 \\
(0.0063)\end{array}$ & $\begin{array}{c}-0.9693 \\
(0.1224)\end{array}$ & $\begin{array}{c}-0.4758 \\
(0.0944)\end{array}$ & $\begin{array}{l}-0.1691 \\
(0.0097)\end{array}$ & $\begin{array}{c}-0.1665 \\
(0.0094)\end{array}$ & $\begin{array}{c}-0.7471 \\
(0.2996)\end{array}$ & $\begin{array}{c}-0.4976 \\
(0.1617)\end{array}$ \\
\hline Country Tax Rate & & & & & $\begin{array}{c}0.1576 \\
(0.0239)\end{array}$ & $\begin{array}{c}0.1106 \\
(0.0246)\end{array}$ & $\begin{array}{c}0.2484 \\
(0.0703)\end{array}$ & $\begin{array}{c}0.1996 \\
(0.0439)\end{array}$ \\
\hline Net PPE/Assets & & & & & $\begin{array}{c}0.0355 \\
(0.0108)\end{array}$ & $\begin{array}{c}0.1102 \\
(0.0159)\end{array}$ & $\begin{array}{c}0.0814 \\
(0.0138)\end{array}$ & $\begin{array}{c}0.0789 \\
(0.0110)\end{array}$ \\
\hline EBITDA/Assets & & & & & $\begin{array}{l}-0.2755 \\
(0.0130)\end{array}$ & $\begin{array}{c}-0.2647 \\
(0.0132)\end{array}$ & $\begin{array}{c}-0.4098 \\
(0.0764)\end{array}$ & $\begin{array}{c}-0.3468 \\
(0.0427)\end{array}$ \\
\hline Log of Sales & & & & & $\begin{array}{l}-0.0044 \\
(0.0017)\end{array}$ & $\begin{array}{c}0.0002 \\
(0.0023)\end{array}$ & $\begin{array}{c}0.0010 \\
(0.0019)\end{array}$ & $\begin{array}{c}0.0001 \\
(0.0015)\end{array}$ \\
\hline Political Risk & & & & & $\begin{array}{c}0.0841 \\
(0.0251)\end{array}$ & $\begin{array}{c}0.1304 \\
(0.0242)\end{array}$ & $\begin{array}{c}0.1568 \\
(0.0208)\end{array}$ & $\begin{array}{c}0.1466 \\
(0.0209)\end{array}$ \\
\hline Average Rate of Inflation & & & & & $\begin{array}{c}0.0005 \\
(0.0011)\end{array}$ & $\begin{array}{c}0.0010 \\
(0.0009)\end{array}$ & $\begin{array}{c}-0.0001 \\
(0.0012)\end{array}$ & $\begin{array}{c}0.0006 \\
(0.0011)\end{array}$ \\
\hline \multicolumn{9}{|l|}{ Parent, Industry, and Year } \\
\hline Fixed Effects? & $\mathrm{N}$ & $\mathrm{Y}$ & $\mathrm{Y}$ & $\mathrm{Y}$ & $\mathrm{N}$ & $\mathrm{Y}$ & $\mathrm{Y}$ & $\mathrm{Y}$ \\
\hline IV using Private Credit & $\mathrm{N}$ & $\mathrm{N}$ & Y & $\mathrm{N}$ & $\mathrm{N}$ & $\mathrm{N}$ & Y & $\mathrm{N}$ \\
\hline IV using Creditor Rights & $\mathrm{N}$ & $\mathrm{N}$ & $\mathrm{N}$ & $\mathrm{Y}$ & $\mathrm{N}$ & $\mathrm{N}$ & $\mathrm{N}$ & $\mathrm{Y}$ \\
\hline $\begin{array}{l}\text { No. of Obs. } \\
\text { R-Squared }\end{array}$ & $\begin{array}{l}44,855 \\
0.0259\end{array}$ & $\begin{array}{l}44,855 \\
0.2490\end{array}$ & 42,996 & 40,293 & $\begin{array}{l}20,649 \\
0.0895\end{array}$ & $\begin{array}{l}20,649 \\
0.3129\end{array}$ & 20,088 & 19,305 \\
\hline \multicolumn{9}{|c|}{$\begin{array}{l}\text { Note: The dependant variable is the ratio of the difference between current liabilities and long term debt an affiliate borrows from and lends to its U.S. parent to total affiliate } \\
\text { assets. Current Liabilities and Long Term Debt Owed to Non-Parents/Assets is the ratio of current liabilities and long term debt an affiliate borrows from non-parent sources } \\
\text { to total affiliate assets. Country Tax Rate is the median tax rate in an affiliate's host country. Net PPE/Assets is the ratio of affiliate net property, plant and equipment to total } \\
\text { affiliate assets. EBITDA/Assets is the ratio of affiliate earnings before interest, taxes, depreciation and amortization to total affiliate assets. Log of Sales is the natural log of } \\
\text { affiliate sales. Political Risk is an index of the average level of political risk over the 1982-1994 period derived from the International Country Risk Guide, rescaled to lie } \\
\text { between } 0 \text { and } 1 \text { with higher numbers indicating higher risks. Average Rate of Inflation is the average percentage change in the GDP deflator of an affiliate's host country } \\
\text { over the } 1982-1994 \text { period. The specifications in columns } 1,2,5 \text { and } 6 \text { are estimated by ordinary least squares. The specifications in column } 3 \text { and } 7 \text { instrument for Current } \\
\text { Liabilities and Long Term Debt Owed to Non-Parents/Assets using Private Credit. Private Credit is the ratio of private credit lent by deposit money banks to GDP, as } \\
\text { provided in Beck, Demirguc-Kunt, and Levine (1999). The specifications in column } 4 \text { and } 8 \text { instrument for Current Liabilities and Long Term Debt Owed to Non- } \\
\text { Parents/Assets using Creditor Rights. Creditor Rights is an index of the strength of creditor rights developed in LaPorta, Lopez-de-Silanes, Shleifer, and Vishny (1998); } \\
\text { higher levels of the measure which ranges from } 0 \text { to } 4 \text { indicate stronger legal protections. Specificiations in columns 2, 3, 4, 6, 7, and } 8 \text { include parent, industry, and year } \\
\text { fixed effects. Standard errors are presented in parentheses, and in columns 1,2, 5, and } 6 \text { these errors correct for clustering of errors across observations in country/industry } \\
\text { cells. }\end{array}$} \\
\hline
\end{tabular}


Table A1

The Substitutability of Parent and External Debt

Dependent Variable: Net Current Liabilities and Long Term Debt Owed to Parent/Owners' Equity

(1)

(2)

(3)

(4)

(5)

(6)

(7)

(8)

\begin{tabular}{|c|c|c|c|c|c|c|c|c|}
\hline Constant & $\begin{array}{c}0.1342 \\
(0.0062)\end{array}$ & $\begin{array}{l}-0.0035 \\
(0.0345)\end{array}$ & $\begin{array}{c}0.0225 \\
(0.5994)\end{array}$ & $\begin{array}{l}-0.1095 \\
(0.4608)\end{array}$ & $\begin{array}{c}0.1976 \\
(0.0434)\end{array}$ & $\begin{array}{c}-0.3458 \\
(0.1395)\end{array}$ & $\begin{array}{c}-0.4915 \\
(1.1944)\end{array}$ & $\begin{array}{c}0.1964 \\
(0.9228)\end{array}$ \\
\hline $\begin{array}{l}\text { Current Liabilities and Long } \\
\text { Term Debt Owed to Non- } \\
\text { Parents/Owners' Equity }\end{array}$ & $\begin{array}{c}0.0688 \\
(0.0044)\end{array}$ & $\begin{array}{c}0.0723 \\
(0.0044)\end{array}$ & $\begin{array}{l}-0.5039 \\
(0.0972)\end{array}$ & $\begin{array}{l}-0.1959 \\
(0.0767)\end{array}$ & $\begin{array}{c}0.0801 \\
(0.0064)\end{array}$ & $\begin{array}{c}0.0825 \\
(0.0069)\end{array}$ & $\begin{array}{c}-0.4599 \\
(0.2369)\end{array}$ & $\begin{array}{c}-0.3642 \\
(0.2186)\end{array}$ \\
\hline Country Tax Rate & & & & & $\begin{array}{c}0.2068 \\
(0.0532)\end{array}$ & $\begin{array}{c}0.1361 \\
(0.0590)\end{array}$ & $\begin{array}{c}0.8244 \\
(0.3016)\end{array}$ & $\begin{array}{c}0.7456 \\
(0.2883)\end{array}$ \\
\hline Net PPE/Assets & & & & & $\begin{array}{c}0.0501 \\
(0.0327)\end{array}$ & $\begin{array}{c}0.1511 \\
(0.0404)\end{array}$ & $\begin{array}{c}0.0669 \\
(0.0515)\end{array}$ & $\begin{array}{c}0.0867 \\
(0.0463)\end{array}$ \\
\hline EBITDA/Assets & & & & & $\begin{array}{c}-0.3924 \\
(0.0310)\end{array}$ & $\begin{array}{c}-0.4139 \\
(0.0347)\end{array}$ & $\begin{array}{l}-0.8925 \\
(0.2123)\end{array}$ & $\begin{array}{c}-0.8344 \\
(0.2044)\end{array}$ \\
\hline Log of Sales & & & & & $\begin{array}{c}-0.0110 \\
(0.0037)\end{array}$ & $\begin{array}{c}0.0012 \\
(0.0046)\end{array}$ & $\begin{array}{c}0.0298 \\
(0.0145)\end{array}$ & $\begin{array}{c}0.0266 \\
(0.0137)\end{array}$ \\
\hline Political Risk & & & & & $\begin{array}{c}0.1508 \\
(0.0558)\end{array}$ & $\begin{array}{c}0.2958 \\
(0.0624)\end{array}$ & $\begin{array}{c}0.5006 \\
(0.1034)\end{array}$ & $\begin{array}{c}0.4214 \\
(0.1061)\end{array}$ \\
\hline Average Rate of Inflation & & & & & $\begin{array}{l}-0.0028 \\
(0.0027)\end{array}$ & $\begin{array}{c}-0.0012 \\
(0.0029)\end{array}$ & $\begin{array}{c}-0.0141 \\
(0.0068)\end{array}$ & $\begin{array}{c}-0.0094 \\
(0.0062)\end{array}$ \\
\hline Parent, Industry, and Year & & & & & & & & \\
\hline Fixed Effects? & $\mathrm{N}$ & $\mathrm{Y}$ & $\mathrm{Y}$ & $\mathrm{Y}$ & $\mathrm{N}$ & $\mathrm{Y}$ & $\mathrm{Y}$ & $\mathrm{Y}$ \\
\hline IV using Private Credit & $\mathrm{N}$ & $\mathrm{N}$ & $\mathrm{Y}$ & $\mathrm{N}$ & $\mathrm{N}$ & $\mathrm{N}$ & $\mathrm{Y}$ & $\mathrm{N}$ \\
\hline IV using Creditor Rights & $\mathrm{N}$ & $\mathrm{N}$ & $\mathrm{N}$ & $\mathrm{Y}$ & $\mathrm{N}$ & $\mathrm{N}$ & $\mathrm{N}$ & $\mathrm{Y}$ \\
\hline $\begin{array}{l}\text { No. of Obs. } \\
\text { R-Squared }\end{array}$ & $\begin{array}{l}35,056 \\
0.0136\end{array}$ & $\begin{array}{l}35,056 \\
0.2454\end{array}$ & 33,638 & 31,608 & $\begin{array}{l}16,600 \\
0.0372\end{array}$ & $\begin{array}{l}16,600 \\
0.2644\end{array}$ & 16,160 & 15,563 \\
\hline
\end{tabular}

Note: The dependant variable is the ratio of the difference between current liabilities and long term debt an affiliate borrows from and lends to its U.S. parent to total affiliate owners' equity. Current Liabilities and Long Term Debt Owed to Non-Parents/Owners' Equity is the ratio of current liabilities and long term debt an affiliate borrows from non-parent sources to total affiliate owners' equity. Country Tax Rate is the median tax rate in an affiliate's host country. Net PPE/Assets is the ratio of affiliate net property, plant and equipment to total affiliate assets. EBITDA/Assets is the ratio of affiliate earnings before interest, taxes, depreciation and amortization to total affiliate assets. Log of Sales is the natural $\log$ of affiliate sales. Political Risk is an index of the average level of political risk over the 1982-1994 period derived from the International Country Risk Guide, rescaled to lie between 0 and 1 with higher numbers indicating higher risks. Average Rate of Inflation is the average percentage change in the GDP deflator of an affiliate's host country over the 1982-1994 period. The specifications in columns 1, 2, 5 and 6 are estimated by ordinary least squares. The specifications in column 3 and 7 instrument for Current Liabilities and Long Term Debt Owed to Non-Parents/Assets using Private Credit. Private Credit is the ratio of private credit lent by deposit money banks to GDP, as provided in Beck, Demirguc-Kunt, and Levine (1999). The specifications in column 4 and 8 instrument for Current Liabilities and Long Term Debt Owed to Non-Parents/Assets using Creditor Rights. Creditor Rights is an index of the strength of creditor rights developed in LaPorta, Lopez-de-Silanes, Shleifer, and Vishny (1998); higher levels of the measure which ranges from 0 to 4 indicate stronger legal protections. Specificiations in columns 2, 3, 4, 6, 7, and 8 include parent, industry, and year fixed effects. Standard errors are presented in parentheses, and in columns 1, 2, 5, and 6 these errors correct for clustering of errors across observations in country/industry cells. All observations in which owners equity is less than 0 are dropped. 